\title{
Ice supersaturations and cirrus cloud crystal numbers
}

\author{
M. Krämer ${ }^{1}$, C. Schiller ${ }^{1}$, A. Afchine ${ }^{1}$, R. Bauer ${ }^{1}$, I. Gensch ${ }^{1}$, A. Mangold ${ }^{1, *}$, S. Schlicht ${ }^{1, * *}$, N. Spelten ${ }^{1}$, N. Sitnikov ${ }^{2}$, \\ S. Borrmann ${ }^{3}$, M. de Reus ${ }^{3}$, and P. Spichtinger ${ }^{4}$ \\ ${ }^{1}$ Forschungszentrum Jülich, Institut fur Chemie und Dynamik der Geosphäre 1: Stratosphäre, 52425 Jülich, Germany \\ ${ }^{2}$ Central Aerological Observatory, Dolgoprudny, Region Moscow, Russia \\ ${ }^{3}$ Institut für Physik der Atmosphäre, Johannes Gutenberg-Universität, Joh.-Joachim-Becher-Weg 21, 55099 Mainz, Germany \\ ${ }^{4}$ ETH Zürich, Institut für Atmosphäre und Klima, Universitätstrasse 16, 8092 Zürich, Switzerland \\ *now at: Royal Meteorological Institute of Belgium, Avenue Circulaire 3, 1180 Brussels, Belgium \\ ** now at: Mühlenbachstraße 5, 52134 Herzogenrath, Germany
}

Received: 20 October 2008 - Published in Atmos. Chem. Phys. Discuss.: 17 December 2008

Revised: 17 April 2009 - Accepted: 24 April 2009 - Published: 3 June 2009

Abstract. Upper tropospheric observations outside and inside of cirrus clouds indicate water vapour mixing ratios sometimes exceeding water saturation. Relative humidities over ice $\left(\mathrm{RH}_{\text {ice }}\right)$ of up to and more than $200 \%$ have been reported from aircraft and balloon measurements in recent years.

From these observations a lively discussion continues on whether there is a lack of understanding of ice cloud microphysics or whether the water measurements are tainted with large uncertainties or flaws.

Here, $\mathrm{RH}_{\text {ice }}$ in clear air and in ice clouds is investigated. Strict quality-checked aircraft in situ observations of $\mathrm{RH}_{\text {ice }}$ were performed during 28 flights in tropical, mid-latitude and Arctic field experiments in the temperature range 183-240 K. In our field measurements, no supersaturations above water saturation are found. Nevertheless, super- or subsaturations inside of cirrus are frequently observed at low temperatures $(<205 \mathrm{~K})$ in our field data set. To explain persistent $\mathrm{RH}_{\text {ice }}$ deviating from saturation, we analysed the number densities of ice crystals recorded during 20 flights. From the combined analysis - using conventional microphysics - of supersaturations and ice crystal numbers, we show that the high, persistent supersaturations observed inside of cirrus can possibly be explained by unexpected, frequent very low ice crystal numbers that could scarcely be caused by homogeneous ice nucleation. Heterogeneous ice formation or the suppression of freezing might better explain the observed ice crystal numbers.

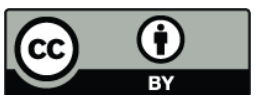

Correspondence to: $\mathrm{M}$. Krämer (m.kraemer@fz-juelich.de)
Thus, our lack of understanding of the high supersaturations, with implications for the microphysical and radiative properties of cirrus, the vertical redistribution of water and climate, is traced back to the understanding of the freezing process at low temperatures.

\section{Introduction}

The relative humidity over ice $\left(\mathrm{RH}_{\text {ice }}\right)$ controls the formation of cirrus clouds in the upper troposphere. Prior to ice formation, when an air parcel cools while rising, $\mathrm{RH}_{\text {ice }}$ increases up to the freezing threshold necessary to nucleate ice in the ambient aerosol particles. Alfred Wegener was probably the first to recognize that atmospheric air can be supersaturated with respect to ice without forming ice crystals. During his second expedition to Greenland in 1911/1912 he recognized that the moist breath of his horses produced small ice crystals (Wall, 1942) growing in the ice supersaturated air. Gierens et al. (2000) and Spichtinger et al. (2003) recalled the work of Glückauf (1945) and Weickmann (1945), mentioning that cirrus clouds do not form "as soon as ice saturation is reached" and that "ice-forming regions in the upper troposphere are regions of high ice supersaturation" that should occur frequently.

Today's state of knowledge is that the freezing thresholds depend on the compounds of the available ice-forming aerosol particles. If these particles are pure liquid solutions (of arbitrary composition), the - homogeneous - freezing thresholds range for $140 \ldots 180 \%$ for $T=240 \ldots 180 \mathrm{~K}$ and are well described by the theory derived by Koop et al. (2000).

Published by Copernicus Publications on behalf of the European Geosciences Union. 
In the presence of aerosol particles containing an insoluble impurity (so called ice nuclei, IN, such as soot, mineral dust or biological particles), the - heterogeneous - freezing thresholds are determined by the composition of the particles. Therefore, up to now no simple parametrisation scheme exists for the heterogeneous freezing thresholds. In most cases they are lower than the homogeneous freezing thresholds and can be significantly different. Thus, injection of aerosol particles with a lower freezing threshold would directly impact the cirrus cloud cover and thus the radiation balance of the atmosphere (Gettelman and Kinnison, 2007).

Once the ice cloud has formed, the gas phase water and thus $\mathrm{RH}_{\text {ice }}$ is depleted by the growing ice crystals as a function of their number and size. The ice cloud microphysics interact with in-cloud $\mathrm{RH}_{\text {ice }}$ (see e.g. Gensch et al., 2008, Comstock and Ackerman, 2008) because it affects the water vapour condensation rate and fall speed of the ice crystals (Khvorostyanov et al., 2006), which in turn influences the vertical redistribution of water in the upper troposphere.

Due to the recent insight that both the clear sky and incloud $\mathrm{RH}_{\text {ice }}$ are important for the Earth's climate, many airborne and remote sensing experiments as well as model studies have recently been performed to investigate the distributions of $\mathrm{RH}_{\text {ice }}$ in the upper troposphere (Kelly et al., 1993; Heymsfield and Milosevitch, 1995; Heymsfield et al., 1998; Gierens et al., 1999, 2000; Jensen et al., 2001, 2005a,b; Ovarlez et al., 2002; Haag et al., 2003; Spichtinger et al., 2003, 2004; Gayet et al., 2004, 2006; Comstock and Ackerman, 2004; Lee et al., 2004; Gao et al., 2004; Gettelman et al., 2006; Korolev and Isaac, 2006; MacKenzie et al., 2006; Popp et al., 2007; H. Vömel, personal communication, 2008; Immler et al., 2008).

The major results of these studies are sorted into two temperature ranges $(T<200 \mathrm{~K}$ and $T=200-240 \mathrm{~K})$ and are listed in Table 1. The warmer temperature range corresponds to cirrus at altitudes between about 6 and $15 \mathrm{~km}$ in Arctic, midlatitude and tropical regions, while cirrus in the colder temperature range is found in the tropics between about 15 and $20 \mathrm{~km}$. Since most aircraft can reach only the lower altitudes, the warmer cirrus clouds and their environment have been more extensively investigated and thus a quite consistent picture already exists.

At higher temperatures ( $T>200 \mathrm{~K})$, supersaturations up to the homogeneous freezing threshold frequently occur under clear sky conditions as well as inside of cirrus clouds. Occasionally higher supersaturations were observed. At lower temperatures $(T<200 \mathrm{~K})$, where the $\mathrm{H}_{2} \mathrm{O}$ concentrations are much lower so that the measurements become challenging for the water instruments, the observations become less frequent. In many of the aircraft and balloon studies, $\mathrm{RH}_{\text {ice }}$ up to or even more than water saturation were reported outside and inside of the cold cirrus clouds.

As outlined earlier, we can understand supersaturations up to the freezing thresholds in both clear air as well as inside cirrus. However, supersaturations up to water saturation or even above raise the question of whether these are caused by instrument artifacts or wether "the basic principles underpinning the current understanding of ice cloud formation and alter the assessment of water distribution in the upper troposphere are called into question", as Peter et al. (2006) summarized the situation.

Another crucial point in this context is the existence of persistently high supersaturations inside of cirrus clouds. It is believed that the in-cloud initially high supersaturation is reduced to saturation very quickly - in the timescale of minutes - through the consumption of gas phase water by the numerous growing ice crystals formed by homogeneous freezing, which is believed to be the major process forming ice in the upper troposphere (Hoyle et al., 2005). However, Korolev and Mazin (2003) showed that one important parameter controlling the water vapour relaxation time and $\mathrm{RH}_{\text {ice }}$ is the product of the mean number and size of the ice crystals, $N_{\text {ice }} \cdot R_{\text {ice }}$, the so-called integral ice crystal radius, which is inversely linked to $\mathrm{RH}_{\text {ice }}$. Thus, in the case of low $\mathrm{N}_{\text {ice }} \cdot \mathrm{R}_{\text {ice }}$, $\mathrm{RH}_{\text {ice }}$ could also become persistent.

Here, we present an extensive data set of strongly quality checked in situ clear sky and in-cloud aircraft observations of $\mathrm{RH}_{\text {ice }}$ and $\mathrm{N}_{\text {ice }}, \mathrm{R}_{\text {ice }}$ in the temperature range $183-240 \mathrm{~K}$. The measurements were performed during 28 flights in the framework of ten field campaigns in the Arctic, at mid-latitudes and in the tropics. Based on the comprehensive field data set, we examine the possible atmospheric range of supersaturations and relaxation times resulting from the observed cirrus microphysical parameters for the complete ice cloud temperature range. We further derive frequencies of occurrence of $\mathrm{RH}_{\text {ice }}$ in $1 \mathrm{~K}$ temperature bins and discuss the pattern of $\mathrm{RH}_{\text {ice }}$ found in clear air and inside of cirrus as well as those of $\mathrm{N}_{\mathrm{ice}}$, $\mathrm{R}_{\text {ice }}$. Finally, we investigate the freezing mechanism consistent with the observed ice crystal numbers for warmer and colder cirrus. We show that there is a strong indication that cold ice clouds $(<205 \mathrm{~K})$ contain a lower ice crystal number than expected.

\section{Aircraft measurements}

Water vapour and ice crystal measurements from several instruments operated on three different research aircraft, i.e. the high-altitude Russian M55 Geophysika and the German research aircraft enviscope-Learjet and DLR Falcon, are analysed in the present study. Only a brief description of each instrument is given here as greater detail is available in the referenced literature. The instruments and the parameters derived from their measurements are listed in Table 2, the campaigns and flights are listed in Table 3.

\subsection{Water vapour}

During field experiments with the M55 Geophysika, water vapour was determined simultaneously with FISH and 
Table 1. Observations of supersaturations in clear air and inside of cirrus clouds.

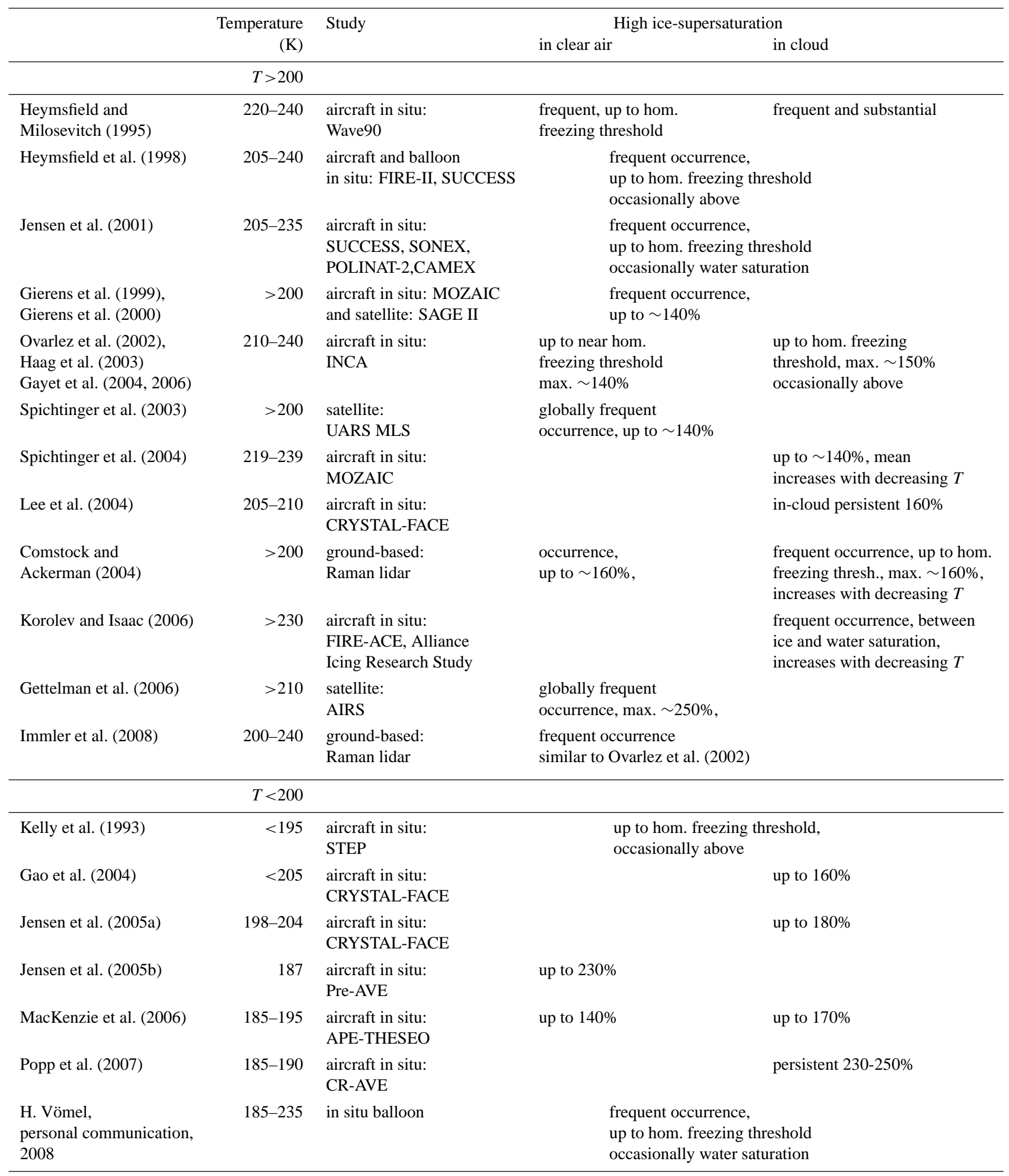


Table 2. Instruments and parameters used during aircraft experiments (FISH: Fast in situ Stratospheric Hygrometer; OJSTER: Open path Jülich Stratospheric Tdl ExpeRiment, FLASH: FLuorescent Airborne Stratospheric Hygrometer, FSSP: Forward Scattering Spectrometer Probe; TDC: Thermo Dynamic Complex; all instruments except FSSP are operated at $1 \mathrm{~Hz}, \mathrm{FSSP}$ at $2 \mathrm{~Hz}$ ).

\begin{tabular}{|c|c|c|c|c|c|}
\hline Quantity & & Description & Instrument & Remarks & Uncertainty \\
\hline $\mathrm{H}_{2} \mathrm{O}_{\mathrm{enh}}$ & (ppmv) & Gas phase $\mathrm{H}_{2} \mathrm{O}+$ enhanced ice & $\mathrm{FISH}^{\star}$ & $\star$ Lyman- $\alpha$-hygrometer & $6 \% \pm 0.2 \mathrm{ppmv}$ \\
\hline $\mathrm{H}_{2} \mathrm{O}_{\text {gas, orig }}$ & (ppmv) & Original gas phase $\mathrm{H}_{2} \mathrm{O}$ & FLASH $^{\star} / \mathrm{OJSTER}^{\dagger}$ & $\dagger$ Open path TDL & $8 \% \pm 0.3 \mathrm{ppmv}$ \\
\hline $\mathrm{H}_{2} \mathrm{O}_{\text {gas, adj }}$ & (ppmv) & Adjusted gas phase $\mathrm{H}_{2} \mathrm{O}$ & FISH, FLASH/OJSTER & see text & $10-15 \%$ \\
\hline $\mathrm{H}_{2} \mathrm{O}_{\text {gas }}$ & (ppmv) & Processed gas phase $\mathrm{H}_{2} \mathrm{O}$ & FISH, FLASH/OJSTER & see text & $10-15 \%$ \\
\hline IWC & (ppmv) & Ice water content & FISH, FLASH/OJSTER & $\frac{\mathrm{H}_{2} \mathrm{O}_{\mathrm{enh}}-\mathrm{H}_{2} \mathrm{O}_{\mathrm{gas}}}{\text { Enhancement }}$ & $10-15 \%$ \\
\hline $\mathrm{RH}_{\text {ice }}$ & $(\%)$ & Relative humidity wrt ice & FISH, FLASH/OJSTER & $\mathrm{H}_{2} \mathrm{O}_{\text {gas }} / \mathrm{H}_{2} \mathrm{O}_{\text {sat }, \text { ice }}$ & $12-17 \%$ \\
\hline $\mathrm{RH}_{\text {ice,enh }}$ & $(\%)$ & Enhanced $\mathrm{RH}_{\text {ice }}$ & FISH & $\mathrm{H}_{2} \mathrm{O}_{\text {enh }} / \mathrm{H}_{2} \mathrm{O}_{\text {sat, ice }}$ & $9-14 \%$ \\
\hline $\mathrm{H}_{2} \mathrm{O}_{\text {sat, ice }}$ & (Pa) & $\mathrm{H}_{2} \mathrm{O}$ vapour saturation wrt ice & Marti and Mauersberger (1993) & $10^{(-2663.5 / T+12.537)}$ & $7 \%$ \\
\hline$T$ & $(\mathrm{~K})$ & Temperature & Avionik, TDC & & $0.5 \mathrm{~K}$ \\
\hline $\mathrm{p}$ & $(\mathrm{hPa})$ & Pressure & Avionik & & $1 \mathrm{hPa}$ \\
\hline $\mathrm{N}_{\text {ice }}$ & $\left(\mathrm{cm}^{-3}\right)$ & Number of ice crystals & FSSP & $\begin{array}{l}\text { Optical particle } \\
\text { spectrometer }\end{array}$ & $10-100 \%$ \\
\hline $\mathrm{R}_{\text {ice }}$ & $(\mu \mathrm{m})$ & Size of ice crystals & FSSP, FISH & $\left.\mathrm{N}_{\text {ice }} \cdot 3 /\left(4 \pi \cdot \rho_{\text {ice }}\right)\right]^{1 / 3}$ & $10-100 \%$ \\
\hline & & \multirow{3}{*}{$\begin{array}{r}\text { on board of DLR Falcon }(12 \mathrm{~km}) \\
\text { enviscope-Learjet }(14 \mathrm{~km}) \\
\text { M55 Geonbyica }(20 \mathrm{~km})\end{array}$} & \multicolumn{2}{|c|}{ FISH, OJSTER, Avionik } & \\
\hline & & & FISH, OJSTER, I & FSSP, Avionik & \\
\hline & & & FISH, FLASH, F & FSSP, Avionik or TDC & \\
\hline
\end{tabular}

FLASH, both closed cell Lyman- $\alpha$ fluorescence hygrometers sampling at $1 \mathrm{~Hz}$ (Zöger et al., 1999 and Schiller et al., 2008, Sitnikov et al., 2007). FISH is equipped with a forward facing inlet sampling $\mathrm{H}_{2} \mathrm{O}_{\text {enh }}$, i.e. gas phase + enhanced ice water. Ice particles are over-sampled with an enhancement ranging from 3 to 10 depending on the inlet geometry and altitude and cruising speed of the aircraft. FLASH uses a downward facing inlet that excludes ice particles and samples only gas phase water, $\mathrm{H}_{2} \mathrm{O}_{\text {gas }}$. In experiments with the German enviscope-Learjet or DLR Falcon, FISH is used for the $\mathrm{H}_{2} \mathrm{O}_{\text {enh }}$ measurements, while $\mathrm{H}_{2} \mathrm{O}_{\text {gas }}$ was measured with the open path TDL OJSTER (MayComm Instruments, May and Webster, 1993). The relative humidity with respect to ice, $\mathrm{RH}_{\text {ice }}$, is calculated from $\mathrm{H}_{2} \mathrm{O}_{\text {gas }}$ and the measurement of the ambient temperature, as listed in Table 2. The term "supersaturation" refers to relative humidities with respect to ice that exceed $100 \%$.

When in a cirrus cloud, $\mathrm{H}_{2} \mathrm{O}_{\text {enh }}$ greatly exceeds $\mathrm{H}_{2} \mathrm{O}_{\text {gas }}$ due to the additional water from the evaporated ice particles which are in addition sampled with an enhanced efficiency (see above). The $\mathrm{H}_{2} \mathrm{O}_{\text {enh }}$ measurements with FISH are important for two reasons: (i) we compare FISH to the other $\mathrm{H}_{2} \mathrm{O}_{\text {gas }}$ instrument in regions outside of clouds to evaluate the agreement between the two water measurements and (ii) we use the difference between $\mathrm{H}_{2} \mathrm{O}_{\text {enh }}$ and $\mathrm{H}_{2} \mathrm{O}_{\text {gas }}$ to determine whether a data point is inside or outside of a cirrus cloud.

\subsection{1 $\mathrm{H}_{2} \mathrm{O}$ data quality}

Figure 1 shows examples of a comparison between the water instruments during some representative flights (a list of all flights is given in Table 3). The upper panel shows a flight with good agreement, at water vapour values between 20 and 200 ppmv during mid-latitude CIRRUS 2004. The dark blue curve represents $\mathrm{H}_{2} \mathrm{O}_{\text {enh }}$, green is the original $\mathrm{H}_{2} \mathrm{O}_{\text {gas }}$ measurement $\mathrm{H}_{2} \mathrm{O}_{\text {gas, orig }}$ and black $\mathrm{H}_{2} \mathrm{O}_{\text {sat,ice. The cyan line is }}$ $\mathrm{H}_{2} \mathrm{O}_{\text {gas }}$,adj, which is determined by adjusting the $\mathrm{H}_{2} \mathrm{O}_{\text {gas }}$, orig measurement to $\mathrm{H}_{2} \mathrm{O}_{\text {enh }}$ in clear air. We chose as the reference the $\mathrm{H}_{2} \mathrm{O}_{\text {enh }}$ observations because FISH is the only instrument that was calibrated in the laboratory before and after each field campaign and in the field before every flight. For the flight shown here the cyan and green data points nearly match each other and this data set is classified as a "good

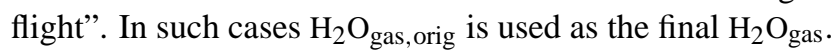

The middle panel shows data from a flight during SCOUT$\mathrm{O}_{3} 2005$ at water vapour values lower than about 5 ppmv. The adjusted data points (cyan) are somewhat higher than the measured (orange), but the differences are nearly constant and the course of the two measurements correspond to each other. Thus, this flight is classified as "acceptable" and $\mathrm{H}_{2} \mathrm{O}_{\text {gas, adj }}$ is used as $\mathrm{H}_{2} \mathrm{O}_{\text {gas }}$ for further analysis. 
Table 3. List of 43 flights from 10 field campaigns using three aircraft (M55 Geophysika, enviscope-Learjet; DLR Falcon). For 37 flights both $\mathrm{H}_{2} \mathrm{O}_{\text {enh }}$ (FISH) and $\mathrm{H}_{2} \mathrm{O}_{\text {gas }}$ (FLASH [Geophysika] or OJSTER [Learjet/Falcon]) were available; $1 / 0$ denotes the agreement of the $\mathrm{H}_{2} \mathrm{O}$ measurements as described in Sect. 2 (1: agreed or adjusted, 0: no agreement, data are rejected from the database), and 20 flights with ice crystal measurements (FSSP) were performed. POLSTAR: Polar Stratospheric Aerosol Experiment, EUPLEX: European Polar Stratospheric Cloud and Lee Wave Experiment, ENVISAT: Envisat validation experiment, CIRRUS: Cirrus characterization experiment, APE-THESEO: Third European Stratospheric Experiment on Ozone, TROCCINOX: Tropical Convection, Cirrus and Nitrogen Oxides Experiment, SCOUT$\mathrm{O}_{3}$ : StratosphericClimate Links with Emphasis on the Upper Troposphere and Lower Stratosphere. The following flights are influenced by convective events: TROCCINOX: 0204-1, SCOUT-O 3 : 1123-1, 1129-1, 1130-1 (Geophysika), 1129-1 (Falcon).

\begin{tabular}{|c|c|c|c|c|c|}
\hline Campaign & Aircraft & Date & $\begin{array}{c}\text { FISH + } \\
\text { FLASH/OJSTER }\end{array}$ & FSSP & Location \\
\hline \multicolumn{6}{|c|}{ ARCTIC } \\
\hline POLSTAR 1998 & Learjet & $0126-1$ & & 1 & Kiruna, Sweden $\left(68^{\circ} \mathrm{N}\right)$ \\
\hline \multirow{5}{*}{ EUPLEX 2003} & Geophysika & 0115-1 & 1 & & Kiruna, Sweden $\left(68^{\circ} \mathrm{N}\right)$ \\
\hline & Geophysika & $0126-1$ & & 1 & \\
\hline & Geophysika & $0208-1$ & 0 & & \\
\hline & Geophysika & 0209-1 & 1 & & \\
\hline & Geophysika & $0211-1$ & & 1 & \\
\hline \multirow[t]{2}{*}{ ENVISAT 2003} & Geophysika & $0302-1$ & 1 & 1 & Kiruna, Sweden $\left(68^{\circ} \mathrm{N}\right)$ \\
\hline & Geophysika & 0316-1 & 1 & 1 & \\
\hline \multicolumn{6}{|c|}{ Mid-Latitude } \\
\hline \multirow[t]{2}{*}{ CIRRUS 2003} & Learjet & $1212-1$ & 1 & & Hohn, Germany $\left(54^{\circ} \mathrm{N}\right)$ \\
\hline & Learjet & $1213-1$ & 1 & & \\
\hline \multirow[t]{2}{*}{ CIRRUS 2004} & Learjet & $1124-1$ & 1 & 1 & Hohn, Germany $\left(54^{\circ} \mathrm{N}\right)$ \\
\hline & Learjet & $1127-1$ & 1 & 1 & \\
\hline \multirow[t]{5}{*}{ CIRRUS 2006} & Learjet & $1124-1$ & 0 & 1 & Hohn, Germany $\left(54^{\circ} \mathrm{N}\right)$ \\
\hline & Learjet & $1127-1$ & 0 & & \\
\hline & Learjet & $1128-1$ & 1 & & \\
\hline & Learjet & $1128-2$ & 1 & & \\
\hline & Learjet & $1129-1$ & 1 & 1 & \\
\hline \multirow[t]{3}{*}{ ENVISAT 2002} & Geophysika & $1008-1$ & 1 & & Forli, Italy \\
\hline & Geophysika & $1014-1$ & 0 & & \\
\hline & Geophysika & $1017-1$ & 0 & & \\
\hline \multicolumn{6}{|c|}{ Tropics } \\
\hline \multirow[t]{2}{*}{ APE-THESEO 1999} & Geophysika & 0219-1 & 1 & & Indian Ocean \\
\hline & Geophysika & 0309-1 & 0 & & \\
\hline \multirow[t]{13}{*}{ SCOUT-O $_{3} 2005$} & Geophysika & $1107-1$ & 1 & & Darwin, Australia $\left(12^{\circ} \mathrm{S}\right)$ \\
\hline & Geophysika & $1109-1$ & 1 & & \\
\hline & Geophysika & $1111-1$ & 1 & & \\
\hline & Geophysika & $1112-1$ & 1 & & \\
\hline & Geophysika & $1119-1$ & 1 & 1 & \\
\hline & Geophysika & $1123-1$ & 1 & & \\
\hline & Geophysika & $1125-1$ & & 1 & \\
\hline & Geophysika & $1129-1$ & 0 & 1 & \\
\hline & Geophysika & $1130-1$ & 1 & 1 & \\
\hline & Geophysika & $1130-2$ & 1 & 1 & \\
\hline & Falcon & $1128-1$ & 1 & & \\
\hline & Falcon & $1129-1$ & 1 & & \\
\hline & Falcon & $1130-2$ & 1 & & \\
\hline \multirow[t]{8}{*}{ TROCCINOX 2005} & Geophysika & $0127-1$ & 1 & & Araçatuba, Brazil $\left(21^{\circ} \mathrm{S}\right)$ \\
\hline & Geophysika & 0201-1 & 1 & & \\
\hline & Geophysika & 0204-1 & 0 & 1 & \\
\hline & Geophysika & $0205-1$ & & 1 & \\
\hline & Geophysika & $0208-1$ & 0 & 1 & \\
\hline & Geophysika & $0217-1$ & & 1 & \\
\hline & Geophysika & 0218-1 & 1 & 1 & \\
\hline & Geophysika & 0224-1 & 1 & 1 & \\
\hline
\end{tabular}



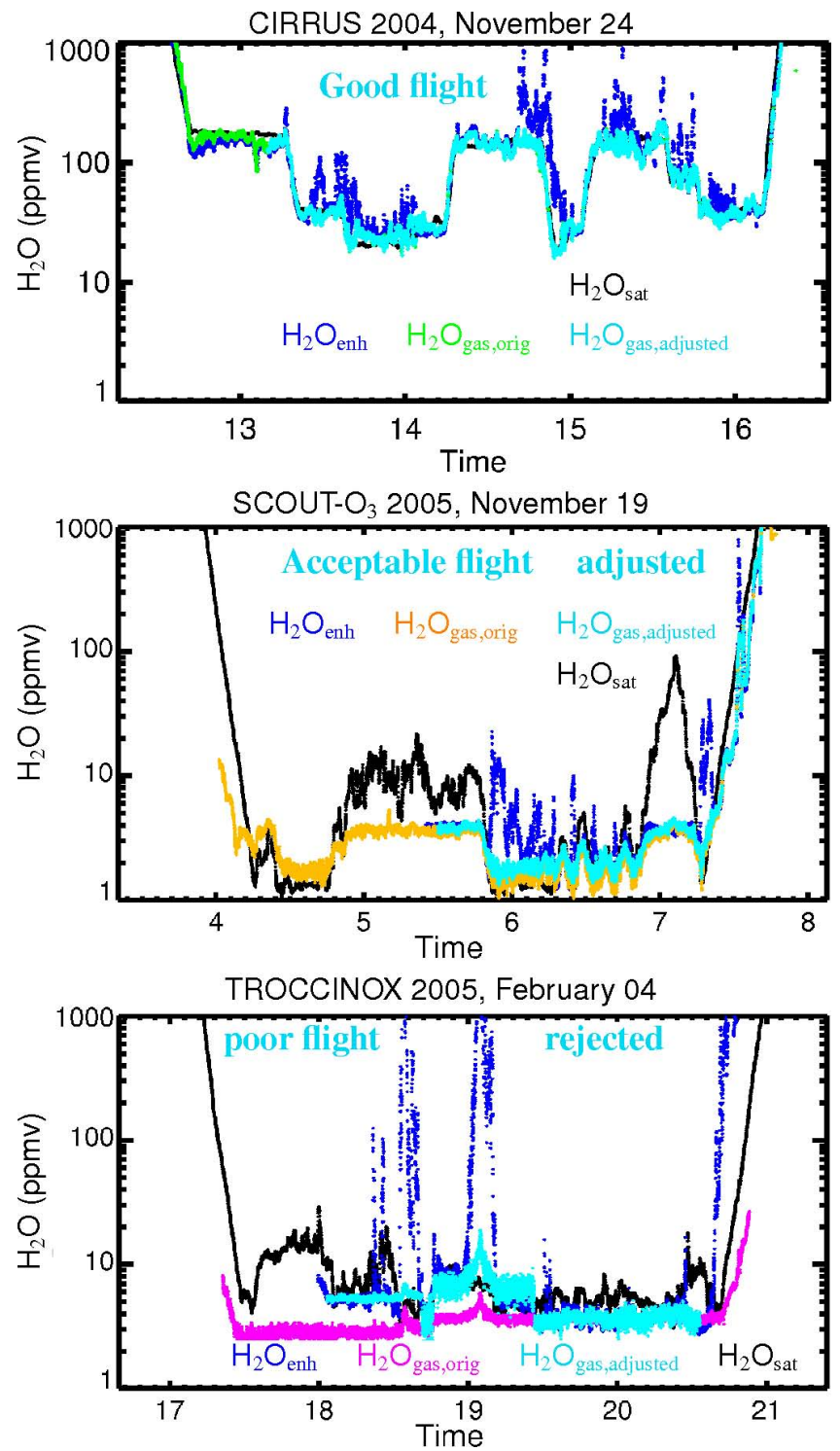

Fig. 1. Examples for $\mathrm{H}_{2} \mathrm{O}$ data quality (upper panel: good flight [FISH/OJSTER]; middle panel: acceptable flight [FISH/FLASH]; bottom panel: poor flight [FISH/FLASH]).

The lowest panel shows a flight also at low water vapour, during TROCCINOX 2005. This is an example of a flight classified as "poor" and rejected from the database as a result of the large scatter between the adjusted and measured values. This means that the characteristics of the two instruments do not match, which is a criterion for discarding a flight.

This data quality check procedure was applied to 37 flights (listed in Table 3) where both $\mathrm{H}_{2} \mathrm{O}_{\text {enh }}$ and $\mathrm{H}_{2} \mathrm{O}_{\text {gas, orig mea- }}$ surements are available. Nine flights (5 at high and 4 at low water vapour mixing ratios) were eliminated so that the database for further analysis of $\mathrm{RH}_{\text {ice }}$ contains 28 flights (see Sect. 3.1).

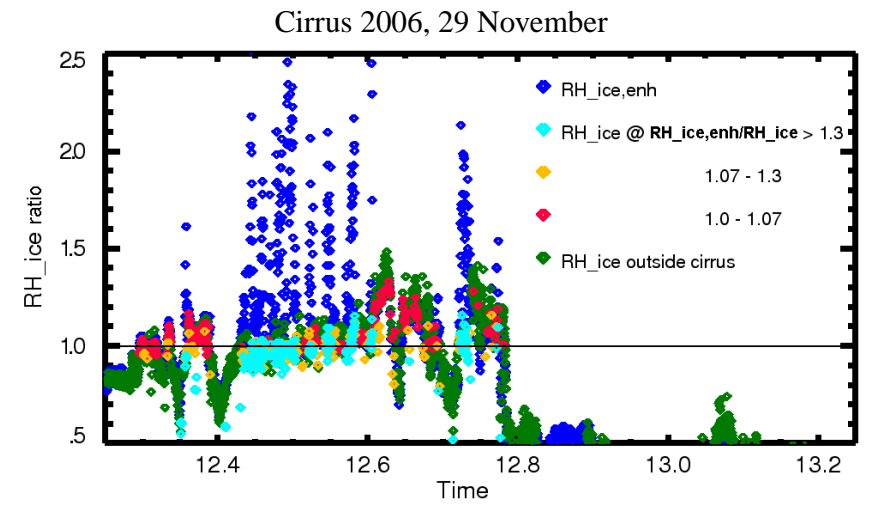

Fig. 2. $\mathrm{RH}_{\mathrm{ice}}(\mathrm{OJSTER})$ and $\mathrm{RH}_{\mathrm{ice}}$,enh $(\mathrm{FISH})$ in the course of the flight Cirrus 2006, 29 November, colour-coded for "cirrusparameter" $\mathrm{RH}_{\text {ice, enh }} / \mathrm{RH}_{\text {ice }}$ to define in/out cirrus (inside cirrus: confident, less confident, uncertain, outside cirrus).

\subsubsection{Cloud detection}

After the data quality check had been applied, the water vapour measurements were evaluated to determine whether the aircraft was in or out of a cloud. For this purpose, ice crystal measurements from the optical particle probes were often used; however, given that these instruments were not always available, a complementary technique was applied that incorporated only the measurements from the water vapour instruments. From the processed $\mathrm{H}_{2} \mathrm{O}_{\text {gas }}$ we calculate $\mathrm{RH}_{\text {ice }}$ and from $\mathrm{H}_{2} \mathrm{O}_{\text {enh }}$ we determine $\mathrm{RH}_{\text {ice,enh. The latter }}$ represents gas phase water plus the over-sampled ice crystals expressed as relative humidity (see Table 2). The ratio $\mathrm{RH}_{\text {ice,enh }} / \mathrm{RH}_{\text {ice }}$ is used as the "cirrus parameter" from which two regimes of cirrus are defined:

Cirrus regime (a) where $\mathrm{RH}_{\text {ice,enh }} / \mathrm{RH}_{\text {ice }}>1$ and $\mathrm{RH}_{\text {ice, enh }}>100 \%$. This regime represents a supersaturated cirrus. In Fig. 2, a part of the "good flight" of Fig. 1 (Cirrus 2006, 29 November) is shown. In Fig. 1 it is seen that both measurements, $\mathrm{H}_{2} \mathrm{O}_{\text {enh }}$ and $\mathrm{H}_{2} \mathrm{O}_{\text {gas }}$ show a scatter that makes it difficult to explicitly state whether a data point is inside cirrus, especially when $\mathrm{RH}_{\text {ice,enh }} / \mathrm{RH}_{\text {ice }}$ only slightly exceeds 1 . Therefore, we discriminate three cirrus classes, differing in the uncertainty of the data points inside the cirrus. In Fig. 2, $\mathrm{RH}_{\text {ice }}$ is colour coded for the three classes: 1) if $\mathrm{RH}_{\text {ice,enh }} / \mathrm{RH}_{\text {ice }}>1.3$ (cyan), a data point is confidently inside cirrus, 2) if $\mathrm{RH}_{\text {ice,enh }} / \mathrm{RH}_{\text {ice }}=1.07-1.3$ (yellow) it is less confident and 3) when $\mathrm{RH}_{\text {ice, enh }} / \mathrm{RH}_{\text {ice }}=1.0-1.07$ (red) it is uncertain whether those measurements were inside the cloud. $\mathrm{RH}_{\text {ice, enh }}$ is plotted in blue and $\mathrm{RH}_{\text {ice }}$ outside of cirrus in green. As already discussed by Schiller et al. (2008) the data points of the third class $\left(\mathrm{RH}_{\text {ice, enh }} / \mathrm{RH}_{\text {ice }}=1.0-1.07\right)$ are not inside of cirrus in most cases, whereas most of the measurements in the second class are inside of cirrus.

Cirrus regime (b) whereby $\mathrm{RH}_{\text {ice,enh }} / \mathrm{RH}_{\mathrm{ice}}>1$ and $\mathrm{RH}_{\mathrm{ice}, \text { enh }}<100 \%$. This situation may be caused by a 
subsaturated cirrus, but might also be the result of the scatter of the water vapour. Here, we define this as cirrus only when $\mathrm{RH}_{\text {ice,enh }} / \mathrm{RH}_{\text {ice }}>1.3$.

All data points not matching the criterions (a) or (b) are defined as outside of cirrus. However, most of the observed data points used in this analysis are "confident" and, moreover, the "less confident" and "uncertain" data points do not influence the general picture of supersaturations.

\subsubsection{Measurement uncertainties}

The uncertainties are estimated by Gaussian error propagation and are listed in Table 2.

The root mean square uncertainty of $\mathrm{RH}_{\text {ice }}$ is in the range $12-17 \%$. However, as discussed above, although state-ofthe-art, high precision water instruments are used here, the different $\mathrm{H}_{2} \mathrm{O}$ measurements are not always in agreement, especially for aircraft observations, and we adjust $\mathrm{H}_{2} \mathrm{O}_{\text {gas, orig }}$ measurements to $\mathrm{H}_{2} \mathrm{O}_{\text {enh }}$ from FISH. The differences in $\mathrm{RH}_{\text {ice }}$ before the adjustment can be much higher than the estimated uncertainties, particularly at low temperatures.

We would like to emphasize here the need for further improvement of water vapour instrumentation, e.g. higher precision, sensitivity and time resolution, especially for aircraft measurements at low temperatures. Otherwise, a number of scientific questions related to water vapour in the atmosphere will remain unanswered.

\subsection{Ice crystals}

For our data analysis, we also use measurements of total ice crystals number concentrations made with instruments mounted on the M55 Geophysika and the enviscope-Learjet using either an FSSP 100 or 300 (de Reus et al., 2008 and references herein; sampling rate is $2 \mathrm{~Hz}$ ). The flights are listed in Table 3.

FSSP 100/300 sample particles in the size range 1.5$15 / 0.3-20 \mu \mathrm{m}$ radius, and ice crystals larger than this size range were not recorded. For a number of flights during the $\mathrm{SCOUT}-\mathrm{O}_{3}$ field campaign a cloud imaging probe (CIP) was also operated on the Geophysika aircraft to complement FSSP with measurements in the range from $12.5<\mathrm{R}_{\text {ice }}<775 \mu \mathrm{m}$ (de Reus et al., 2008). From these flights we determined at least $80 \%$, but typically more than $90 \%$, of the total number concentration within the FSSP size range in cirrus at temperatures less than $240 \mathrm{~K}$. Thus, the error in $\mathrm{N}_{\mathrm{ice}}$ is small, but the error in the mean ice crystal size $\mathrm{R}_{\text {ice }}$ detected by FSSP could be significant. Therefore, we estimate $\mathrm{R}_{\text {ice }}$ from the IWC detected by FISH (FISH samples all ice crystals larger than $2 \mu \mathrm{m}$ radius, Krämer and Afchine, 2004) together with $\mathrm{N}_{\text {ice }}$ from FSSP by assuming that all crystals are spheres of the same size (see Table 2).

Shattering of ice crystals on the inlet FSSP can lead to an overestimate of the ice crystal concentration and IWC (Gardiner and Hallett, 1985; Field et al., 2006a,b; McFar- quhar et al., 2007; Jensen et al., 2009). This is valid for clouds where the ice crystal population contains a significant number of particles larger than approximately $50 \mu \mathrm{m}$ (D. Baumgardner, personal communication, 2007) and especially when a flow-straightening shroud is present in front of the inlet (Davis et al., 2009). Here, the FSSP does not use a shroud and the largest fraction of our measurements of $\mathrm{R}_{\text {ice }}$ lie between 3-30 $\mu \mathrm{m}$ at temperatures $<200 \mathrm{~K}$ and mostly up to around $50 \mu \mathrm{m}$ at higher temperatures, while $\mathrm{N}_{\text {ice }}$ ranges from 0.005 to $60 \mathrm{~cm}^{-3}$ (see Sect. 3.4).

In agreement with de Reus et al. (2008) and Lawson et al. (2008), we do not expect a significant effect of shattering at low temperatures: Lawson et al. (2008) used a CPI (cloud particle imager), a 2D-S (2-dimensional stereo probe) and a CAPS (cloud and aerosol particle spectrometer) for ice crystal detection up to about $800 \mu \mathrm{m}$ radius during $2.4 \mathrm{~h}$ of observation time below $200 \mathrm{~K}$. Jensen et al. (2009) stated that the 2D-S is less susceptible to shattering artifacts, and Lawson et al. (2008) reported that from the images of 2D-S and CPI there was no visual evidence of shattered particles and that the size distributions of all three instruments were consistent.

We cannot, however, completely exclude ice crystal shattering in the warmer ice clouds where the occurrence of larger ice crystals increases. This is discussed in greater detail in Sect. 3.5.3.

\section{Results and discussion}

\subsection{Cirrus field observations}

Altogether, $20.8 \mathrm{~h} \mathrm{(about} 14150 \mathrm{~km}$ ) and $15.4 \mathrm{~h}$ (about $10470 \mathrm{~km}$ ) of flight time was spent in clear sky and inside of cirrus, respectively. Inside of cirrus, a wide range of conditions at different latitudes $\left(20^{\circ}\right.$ south to $75^{\circ}$ north $)$, altitudes $(6-20 \mathrm{~km})$ and temperatures $(183-240 \mathrm{~K})$ is spanned. The observations include frontal and lee wave cirrus in the Arctic and at mid-latitudes, while in the tropics ice crystals stemming from convection and convective outflow as well as subvisible cirrus layers are probed equally. It should be noted here that we assume that the cirrus observations are not biased by the flight pattern. In most of the flights, the aircraft probed the cirrus clouds from top to bottom.

The original field measurements of $\mathrm{RH}_{\text {ice }}$ derived from $\mathrm{H}_{2} \mathrm{O}_{\text {gas, orig }}$ in- and outside of cirrus for all 37 flights with complete $\mathrm{H}_{2} \mathrm{O}$ measurements (listed in Table 3) are plotted versus temperature in the top panels of Fig. 3. The data are sorted for in- and outside of cirrus and the $\mathrm{H}_{2} \mathrm{O}$ quality check procedure is applied to all flights as described in Sect. 2.1. The processed data are presented in the bottom panels of Fig. 3. Comparison of the processed with the original $\mathrm{RH}_{\text {ice }}$ shows that for temperatures above about $200 \mathrm{~K}$ all supersaturations above the homogeneous freezing threshold disappear for both in- and outside of cirrus 


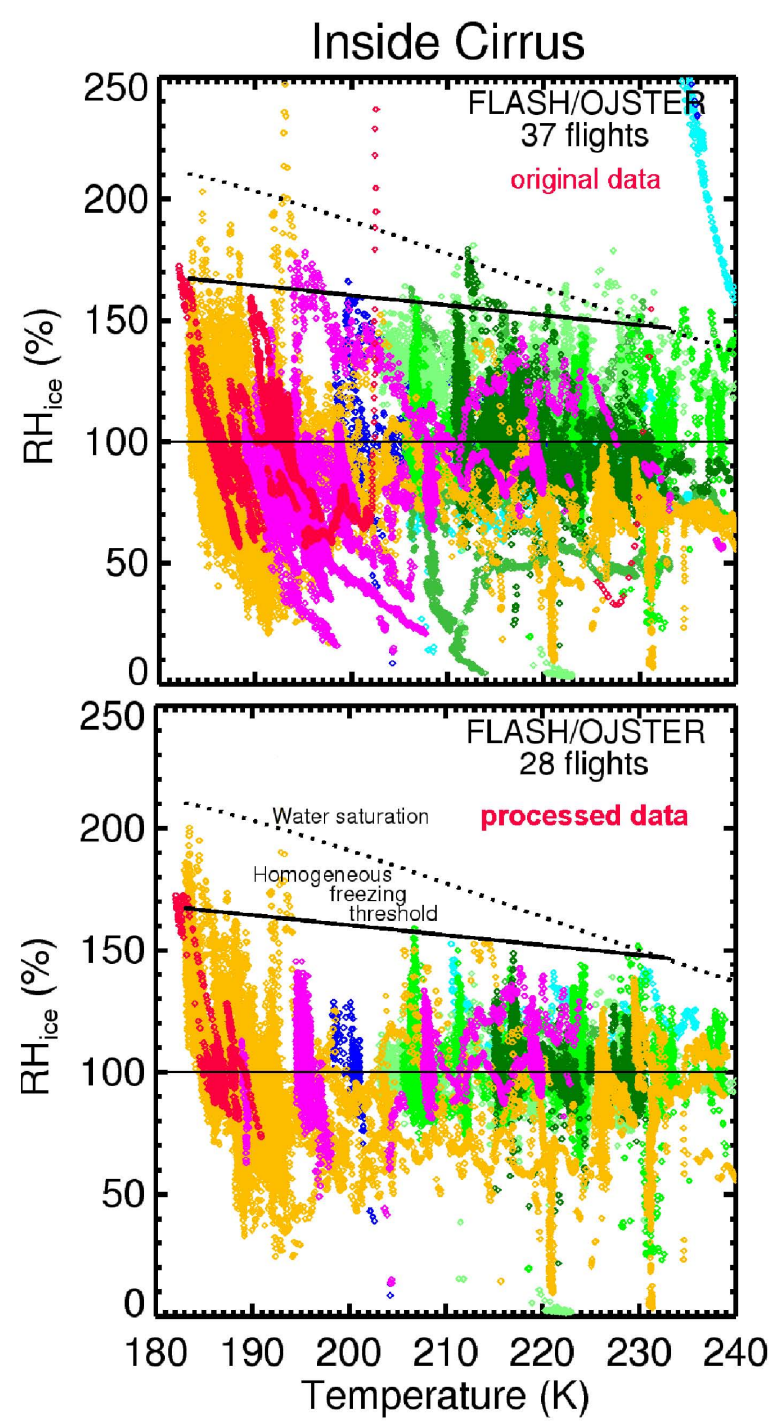

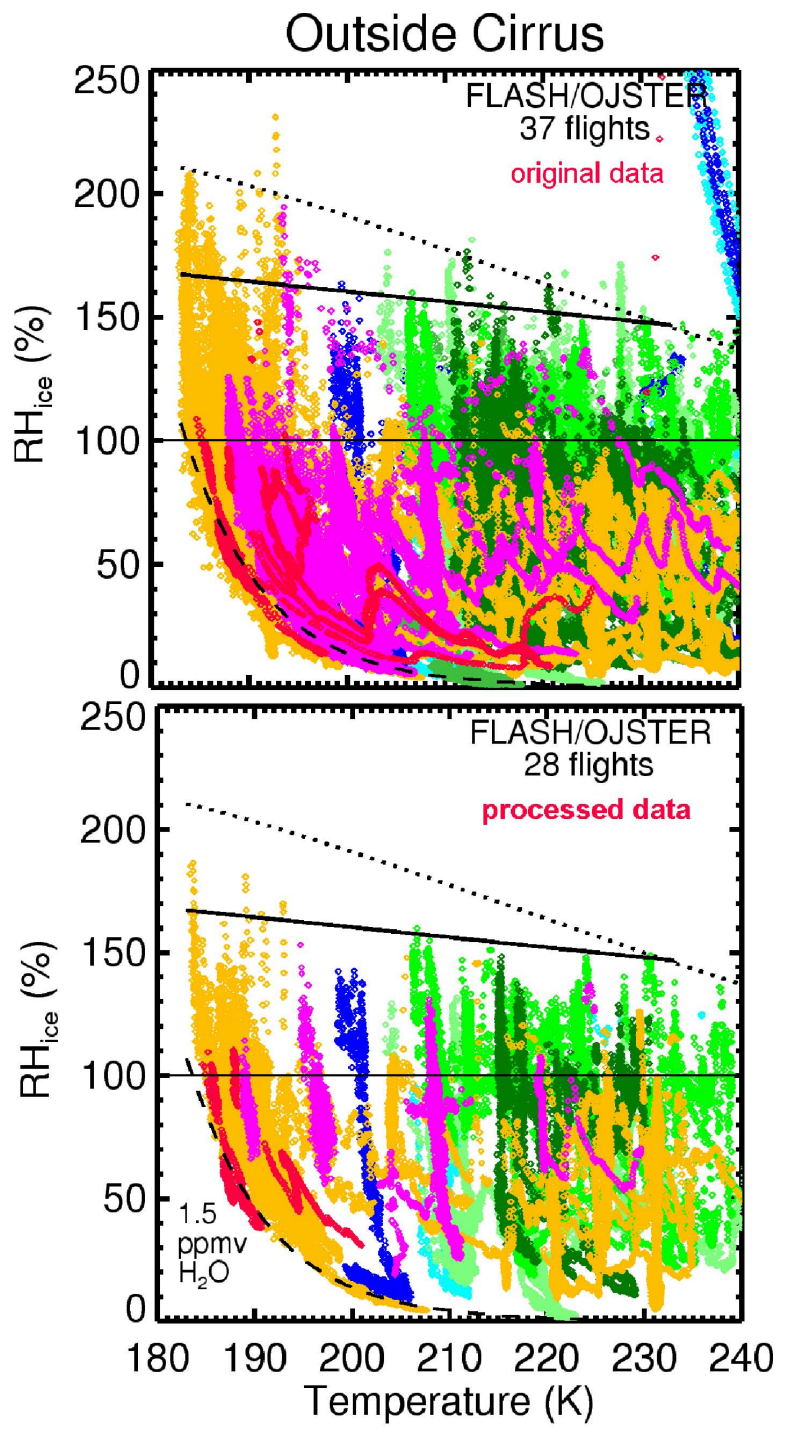

Tropics

$\begin{array}{ll} & \text { Midlatitude } \\ & \\ \text { Envisat 2002, } & 3 \\ \text { CIRRUS 2003, } & 2 \\ \text { - CIRRUS 2004, } & 2 \\ \text { - CIRRUS 2006, } & 5\end{array}$

- ApeTheseo 1999, 2

- Troccinox 2005, 6

Scout 2005, 12

Fig. 3. Field observations of $\mathrm{RH}_{\mathrm{ice}}$ vs. temperature in- and outside of cirrus. Top panels: original $\mathrm{RH}_{\mathrm{ice}}\left(\mathrm{H}_{2} \mathrm{O}_{\text {gas, orig }}\right)$ measurements of all

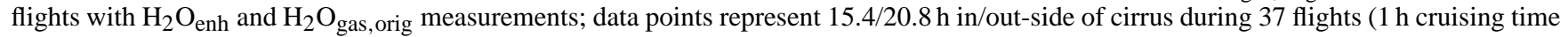
represents about $680 \mathrm{~km}$ ); blueish data points represent Arctic, greenish mid-latitude and reddish tropical field campaigns. Bottom panels: processed $\mathrm{RH}_{\mathrm{ice}}\left(\mathrm{H}_{2} \mathrm{O}_{\text {gas }}\right)$ data; data points represent 9.7/15.9 h in-/outside of cirrus during 28 flights. The black dotted line represents water saturation (water saturation over ice: Marti and Mauersberger, 1993; over water: Tabazadeh et al., 1997), the black solid line the homogeneous freezing threshold for liquid solution droplets with $0.5 \mu \mathrm{m}$ radius (Koop et al., 2000).

observations. Below $200 \mathrm{~K}$, a few supersaturations slightly above the homogeneous freezing threshold are found, which will be discussed in Sects. 3.2 and 3.3.

Comparison of our processed $\mathrm{RH}_{\mathrm{ice}}$ data set with former field measurements during INCA 2000 (10 flights, Ovarlez et al., 2002) and CRYSTAL FACE 2002 (10 flights, Gao et al., 2004) shows that the temperature range of the cirrus observations during CRYSTAL FACE $(\sim 195-215 \mathrm{~K})$ complements the range of INCA $(\sim 215-240 \mathrm{~K})$. 


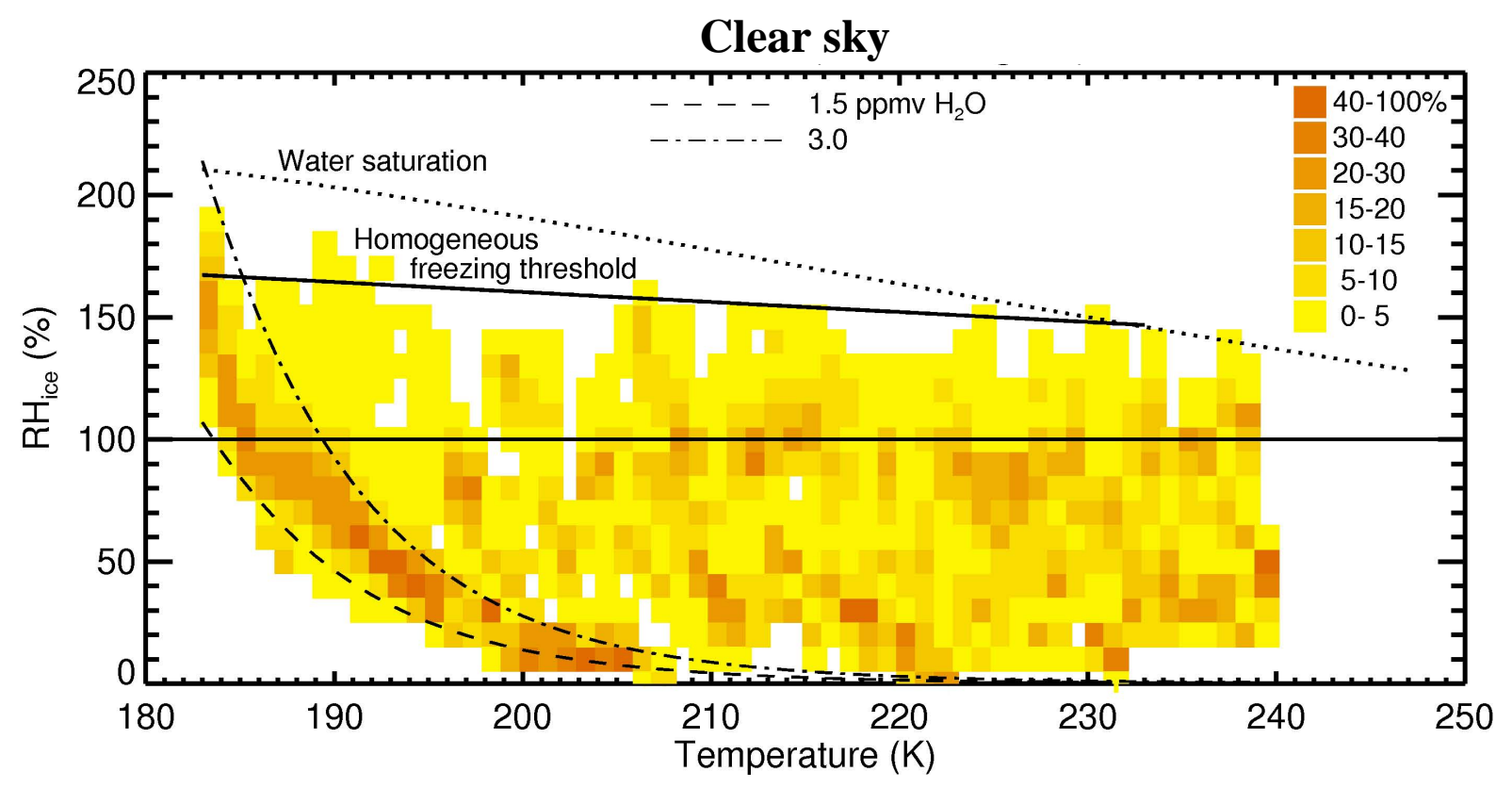

Fig. 4. Same as Fig. 3 (bottom right panel), but as frequencies of occurrence (data are sorted in 1K temperature bins; solid line: homogeneous freezing threshold, dotted line: water saturation line).

In the overall temperature range the general picture from all measurements is that $\mathrm{RH}_{\mathrm{ice}}$ is distributed between subsaturated and supersaturated values close to the homogeneous freezing threshold.

Closer comparison of our clear sky $\mathrm{RH}_{\text {ice }}$ field observations with those from the INCA campaign indicates that the INCA $\mathrm{RH}_{\text {ice }}$ observations are slightly below our measurement range (Fig. 2 in Ovarlez et al., 2002). We explain this feature by a higher time resolution of the in/outside of cloud criterion, which is $1 \mathrm{~s}$ here and $7 \mathrm{~s}$ for INCA. That means the INCA data points are more distant from the cirrus and thus, assuming that the highest $\mathrm{RH}_{\text {ice }}$ are reached immediately before the point of cirrus formation, lower supersaturation seems to be the result.

Gao et al. (2004, their Fig. 1) averaged in-cloud supersaturations from CRYSTAL FACE and proposed an average of $110 \%$ for temperatures above around $205 \mathrm{~K}$, rising to around $130 \%$ for lower temperatures. The enhanced supersaturation at low temperatures is explained by diminished $\mathrm{H}_{2} \mathrm{O}$ uptake of the ice crystals caused by $\mathrm{HNO}_{3}$ deposits on the ice surface. From our measurements, showing a higher data density and extending the temperature range of CRYSTAL FACE down to $182 \mathrm{~K}$, we cannot confirm a constant supersaturation in the two temperature ranges.

Further discussion of the structure of the $\mathrm{RH}_{\text {ice }}$ clear sky and in-cloud observations is provided in Sects. 3.2 (Clear sky $\left.\mathrm{RH}_{\text {ice }}\right), 3.3$ ( $\mathrm{RH}_{\text {ice }}$ inside of cirrus).

\subsection{Clear sky $\mathrm{RH}_{\text {ice }}$}

Under clear sky conditions, supersaturations up to the freezing thresholds of the available aerosol particles may occur in the upper troposphere (see Introduction). From our clear sky observations in the vicinity of cirrus clouds (Fig. 3, bottom right panel and, as frequencies of occurrence, in Fig. 4), representing $15.9 \mathrm{~h}$ of aircraft flight time, it can be seen that for temperatures $>200 \mathrm{~K} \mathrm{RH}_{\text {ice }}$ is randomly distributed between nearly zero up to the homogeneous freezing thresholds. This finding is in agreement with Ovarlez et al. (2002), deriving a frequency distribution for mid-latitude cirrus clouds covering the temperature range $215-235 \mathrm{~K}$ from the INCA field experiment.

For lower temperatures, the upper limit of $\mathrm{RH}_{\text {ice }}$ is in general also the homogeneous freezing line, but a few data points are found slightly above it (see Sect. 3.2). The lower $\mathrm{RH}_{\text {ice }}$ limit is enclosed by the dashed line in Fig. 3 (bottom right panel), representing a constant $\mathrm{H}_{2} \mathrm{O}$ value of $1.5 \mathrm{ppmv}$, the minimum water vapour mixing ratio observed in the upper tropical troposphere. The highest frequencies of occurrence of $\mathrm{RH}_{\text {ice }}$ are enclosed by the dashed lines in Fig. 4, representing constant water vapour mixing ratios of 1.5 and 3 ppmv, which correspond to typical values near the tropical tropopause.

No supersaturations close to or above water saturation are observed in our field measurements. Thus, from our data set we could not confirm the hypothesis of severe suppression of ice cloud formation as given by Jensen et al. (2005b), showing clear sky $\mathrm{RH}_{\text {ice }}$ up to $230 \%$ at tropical tropopause 
temperatures as low as $187 \mathrm{~K}$. Nevertheless, below $200 \mathrm{~K}$ a few cases of supersaturations slightly above the homogeneous freezing threshold are observed, raising the question of whether at these low temperatures the freezing of liquid aerosol particles may occur at higher supersaturations as described by Koop's theory.

Murphy et al. (2007) reported that around 50\% of the aerosol particles in the cold uppermost troposphere contain organic material. Ice nucleation experiments at the AIDA chamber with soot and mineral dust particles containing organic material show that the heterogeneous freezing process of these particles is hindered (Möhler et al., 2005b, 2008). In a model study, Kärcher and Koop (2005) show that homogeneous freezing of solution droplets is hindered in the presence of organics. Laboratory experiments for homogeneous freezing (Beaver et al., 2006) of sulphuric acid aerosols containing differing organic substances show both increasing and decreasing ice nucleation temperatures in dependence on the organic compound. Recent studies by Murray (2008) and Zobrist et al. (2008) investigate the suppression of homogeneous ice crystallization at low temperatures in highly viscous aqueous organic acid droplets or glass-forming aerosol particles. Considering these studies together with our clear sky field observations yields a consistent picture. A further discussion of the freezing suppression is given in Sect. 3.5.

\subsection{In-cloud $\mathbf{R H}_{\text {ice }}$}

Immediately after ice formation, but already inside of an ice cloud, supersaturation is close to the freezing threshold. In the further cirrus lifetime, $\mathrm{RH}_{\text {ice }}$ will, depending on the ice clouds' microphysical and thermodynamical development, adjust to equilibrium in accordance with the water exchange with the ice crystals.

The $\mathrm{RH}_{\text {ice }}$ field data inside of cirrus are shown in Fig. 3 (bottom left panel). Values of $\mathrm{RH}_{\text {ice }}$ are found between around $50 \%$ and the homogeneous thresholds. The lower $\mathrm{RH}_{\text {ice }}$ limit seems to decrease with decreasing temperature, except for two strokes at around 220 and $230 \mathrm{~K}$ dropping down to near zero. These observations stem from flights in tropical thick cirrus at around 14/11 km $\left(\right.$ SCOUT-O $_{3} 2005$, Darwin). Both observations were at the very close edge of the cirrus, maybe in the transition zone between the in/outside of cirrus. The decrease with temperature of the lowest $\mathrm{RH}_{\text {ice }}$ may be explained by longer evaporation times at lower temperatures, causing the ice crystals to survive longer during the evaporation stage of the cloud.

Below $200 \mathrm{~K}$, no supersaturations close to or above water saturation are observed in our field measurements, but a few $\mathrm{RH}_{\text {ice }}$ data above the homogeneous freezing line are found as in the clear sky data set. They may either portray the higher freezing thresholds discussed in Sect. 3.2, or represent the so-called "peak $\mathrm{RH}_{\text {ice" }}$ " in very young, thin cirrus. This peak $\mathrm{RH}_{\text {ice }}$ is described by Kärcher and Lohmann (2002) and is seen in heterogeneous ice nucleation experi- ments at the aerosol chamber AIDA for soot particles coated with sulphuric acid (Möhler et al., 2005a), soot containing organic carbon (Möhler et al., 2005b) and mineral dust particles (Möhler et al., 2006): after ice crystal formation and continuous cooling, $\mathrm{RH}_{\text {ice }}$ still rises up to the peak $\mathrm{RH}_{\text {ice }}$. This further increase in $\mathrm{RH}_{\text {ice }}$ results since the ice crystals are so small or so few at the beginning that the water depletion of the gas phase is not large enough to compensate the increase of $\mathrm{RH}_{\text {ice }}$ caused by the further cooling. The duration and the degree of the post-ice nucleating $\mathrm{RH}_{\text {ice }}$ increase inversely depends on the number of ice crystals, because fewer ice crystals consume the water vapour more slowly and therefore $\mathrm{RH}_{\text {ice }}$ can rise higher. In colder ice clouds, this behaviour becomes more pronounced.

\subsection{Cirrus in dynamical equilibrium}

To further explain the pattern of $\mathrm{RH}_{\text {ice }}$ inside of cirrus we elaborate simple, observation-based theoretical considerations of supersaturations in the dynamical equilibrium of cirrus.

Dynamical equilibrium ("quasi steady state") in ice clouds is described by Korolev and Mazin (2003) as the state where changes in the mean size of the ice particles $\left(\overline{\mathrm{R}_{\mathrm{i}}}\right)$ can be neglected and the ice particle number $\left(\mathrm{N}_{\mathrm{i}}\right)$ and vertical velocity $\left(\mathrm{u}_{\mathrm{z}}\right)$ are nearly constant. changes in supersaturation are then zero $\frac{\mathrm{dRH}_{\text {ice }}}{\mathrm{dt}}=0$ because the gas phase depletion of water by transport to the ice crystals compensates the decrease of the saturation water vapour pressure caused by the cooling. Korolev and Mazin (2003) describe the dynamical equilibrium supersaturation $\mathrm{RH}_{\mathrm{qsi}}$ as

$\mathrm{RH}_{\mathrm{qsi}}=\frac{\mathrm{u}_{\mathrm{z}}}{\mathrm{N}_{\mathrm{i}} \overline{\mathrm{R}_{\mathrm{i}}}} \cdot \frac{\mathrm{a}_{0}}{\mathrm{~b}_{\mathrm{i}}}-\frac{\mathrm{b}_{\mathrm{i}}^{\star}}{\mathrm{b}_{\mathrm{i}}}$

$a_{0}, b_{i}, b_{i}^{\star}$ are parameters depending on temperature, pressure, etc., and $\mathrm{N}_{\mathrm{i}} \overline{\mathrm{R}_{\mathrm{i}}}$ is the integral ice particle radius.

The time the initial in-cloud supersaturation, which is close to the freezing threshold, needs to reach dynamical equilibrium is the relaxation time $\tau$ :

$$
\tau=\frac{1}{\mathrm{a}_{0} \cdot \mathrm{u}_{\mathrm{z}}+\left(\mathrm{b}_{\mathrm{i}}+\mathrm{b}_{\mathrm{i}}^{\star}\right)\left(\mathrm{N}_{\mathrm{i}} \overline{\mathrm{R}_{\mathrm{i}}}\right)}
$$

The main parameters influencing $\mathrm{RH}_{\mathrm{qsi}}$ and $\tau$ are $\mathrm{N}_{\mathrm{i}} \overline{\mathrm{R}}, \mathrm{u}_{\mathrm{z}}$, $T$ (and $\mathrm{p}$, but in the upper tropospheric pressure range this influence is negligible).

From our data set of cirrus ice crystal number densities $\mathrm{N}_{\text {ice }}$ and sizes $\mathrm{R}_{\text {ice }}$ observed during 20 flights (Fig. 5; measurement techniques are described in Sect. 2.2), we can derive atmospheric values of $\mathrm{N}_{\mathrm{i}} \overline{\mathrm{R}_{\mathrm{i}}}$. Firstly, $\mathrm{N}_{\mathrm{i}} \overline{\mathrm{R}_{\mathrm{i}}}$ are identified by encompassing the observed ranges by lines for the minimum ( $\mathrm{N}_{\text {ice }}$ : yellow, $\mathrm{R}_{\mathrm{ice}}$ : green), the middle (both red) and the maximum $\left(\mathrm{N}_{\text {ice }}\right.$ : green, $\mathrm{R}_{\text {ice }}$ : yellow). Secondly, because the number of ice crystals is roughly inversely linked to their size, the $\mathrm{N}_{\text {ice }}$ and $\mathrm{R}_{\text {ice }}$ lines of the same colour are multiplied: 

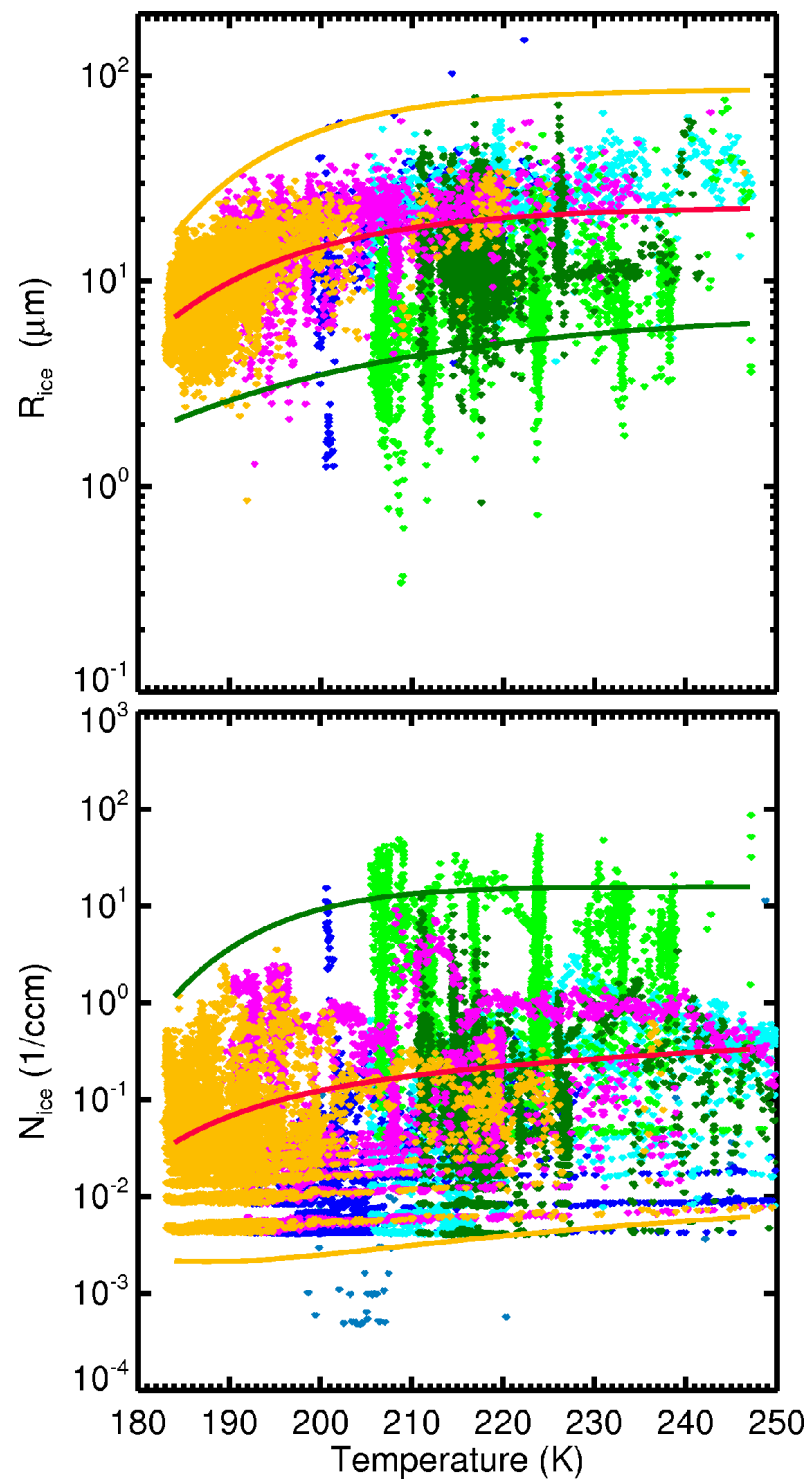

Fig. 5. Ice crystal number $\mathrm{N}_{\text {ice }}$ (bottom) and size $\mathrm{R}_{\text {ice }}$ (top) vs. temperature. Dots: observations from 20 flights $(8.5 \mathrm{~h}$ inside of cirrus, for colour coding see Fig. 3), lines: minimum, middle and maximum $\mathrm{N}_{\text {ice }}$ and $\mathrm{R}_{\text {ice. }}$.

$-\mathrm{N}_{\mathrm{i}} \mathrm{R}_{\mathrm{i}} \min =\mathrm{N}_{\mathrm{ice}, \min } \cdot \mathrm{R}_{\mathrm{ice}, \max }$,

- $\mathrm{N}_{\mathrm{i}} \mathrm{R}_{\mathrm{i}}$ middle $=\mathrm{N}_{\mathrm{ice}}$, middle $\cdot \mathrm{R}_{\mathrm{ice}}$, middle,

$-\mathrm{N}_{\mathrm{i}} \mathrm{R}_{\mathrm{i}} \max =\mathrm{N}_{\text {ice, } \max } \cdot \mathrm{R}_{\mathrm{ice}, \min }$.

Knowing the minimum, middle and maximum of $\mathrm{N}_{\mathrm{i}} \mathrm{R}_{\mathrm{i}}$ as a function of temperature, we calculated the corresponding $\mathrm{RH}_{\mathrm{qsi}}$ and $\tau$ for two vertical velocities $\mathrm{u}_{\mathrm{z}}$, respectively (Fig. 6). A higher and a low $u_{z}$ are chosen for the different $\mathrm{N}_{\mathrm{i}} \mathrm{R}_{\mathrm{i}}$ (thick, medium and thin cirrus) to represent, on the one hand, a young cirrus directly after formation and, on the other hand, an older cirrus at the end of its lifetime. We used different $u_{z}$ for each of the three cloud types, because for
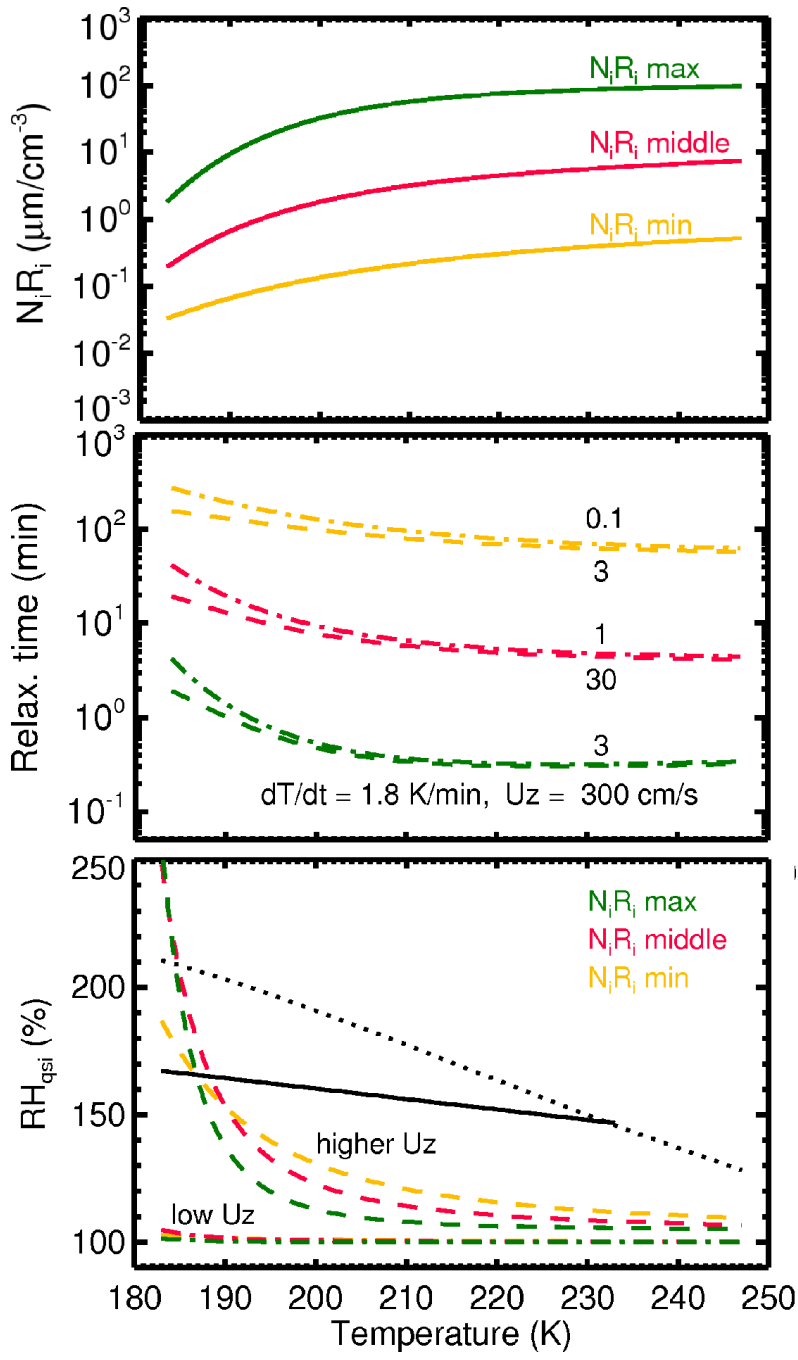

Fig. 6. Quasi steady state relative humidity $\mathrm{RH}_{\mathrm{qsi}}$ (bottom), relaxation times $\tau$ (middle) and integral ice crystal size $\mathrm{N}_{\mathrm{i}} \mathrm{R}_{\mathrm{i}}$ (top) vs. temperature for minimum (yellow), middle (red) and maximum (green) $\mathrm{N}_{\mathrm{i}} \mathrm{R}_{\mathrm{i}}$ and high (dashed)/low (dashed-dotted) vertical velocity $\mathrm{u}_{\mathrm{z}}$, respectively $\left(\mathrm{N}_{\mathrm{i}} \mathrm{R}_{\mathrm{i}}=\mathrm{N}_{\mathrm{ice}} \cdot \overline{\mathrm{R}_{\mathrm{ice}}}\right.$, calculated from the lines in Fig. 5 with $\mathrm{p}=\mathrm{p}_{\text {mean }}(T)$ taken from Schiller et al. (2008), electronic supplement; the black dotted line represents water saturation, the black solid line the homogeneous freezing threshold after Koop et al. (2000); note that the calculations are not for evaporating cirrus, where $\mathrm{u}_{\mathrm{z}}$ is negative and $\mathrm{RH}_{\mathrm{ice}}$ is below saturation); for more information see text.

the frequently occurring homogeneous ice formation process the ice crystal number increases with increasing updraft, i.e. thick clouds are formed at high $\mathrm{u}_{\mathrm{z}}$ and thin cirrus at low $\mathrm{u}_{\mathrm{z}}$ (see also Sect. 3.5). Hence, $u_{z}$ of 300 and $3 \mathrm{~cm} / \mathrm{s}$ (dashed and dashed-dotted green lines) are chosen for the maximum $\mathrm{N}_{\mathrm{i}} \mathrm{R}_{\mathrm{i}}, 30 / 1 \mathrm{~cm} / \mathrm{s}$ for middle $\mathrm{N}_{\mathrm{i}} \mathrm{R}_{\mathrm{i}}$ (red lines) and $3 / 0.1 \mathrm{~cm} / \mathrm{s}$ for the minimum $\mathrm{N}_{\mathrm{i}} \mathrm{R}_{\mathrm{i}}$ (yellow lines).

In young cirrus with higher $\mathrm{u}_{\mathrm{z}}$, the dynamical equilibrium $\mathrm{RH}_{\mathrm{qsi}}$ tends to supersaturation over the complete temperature 


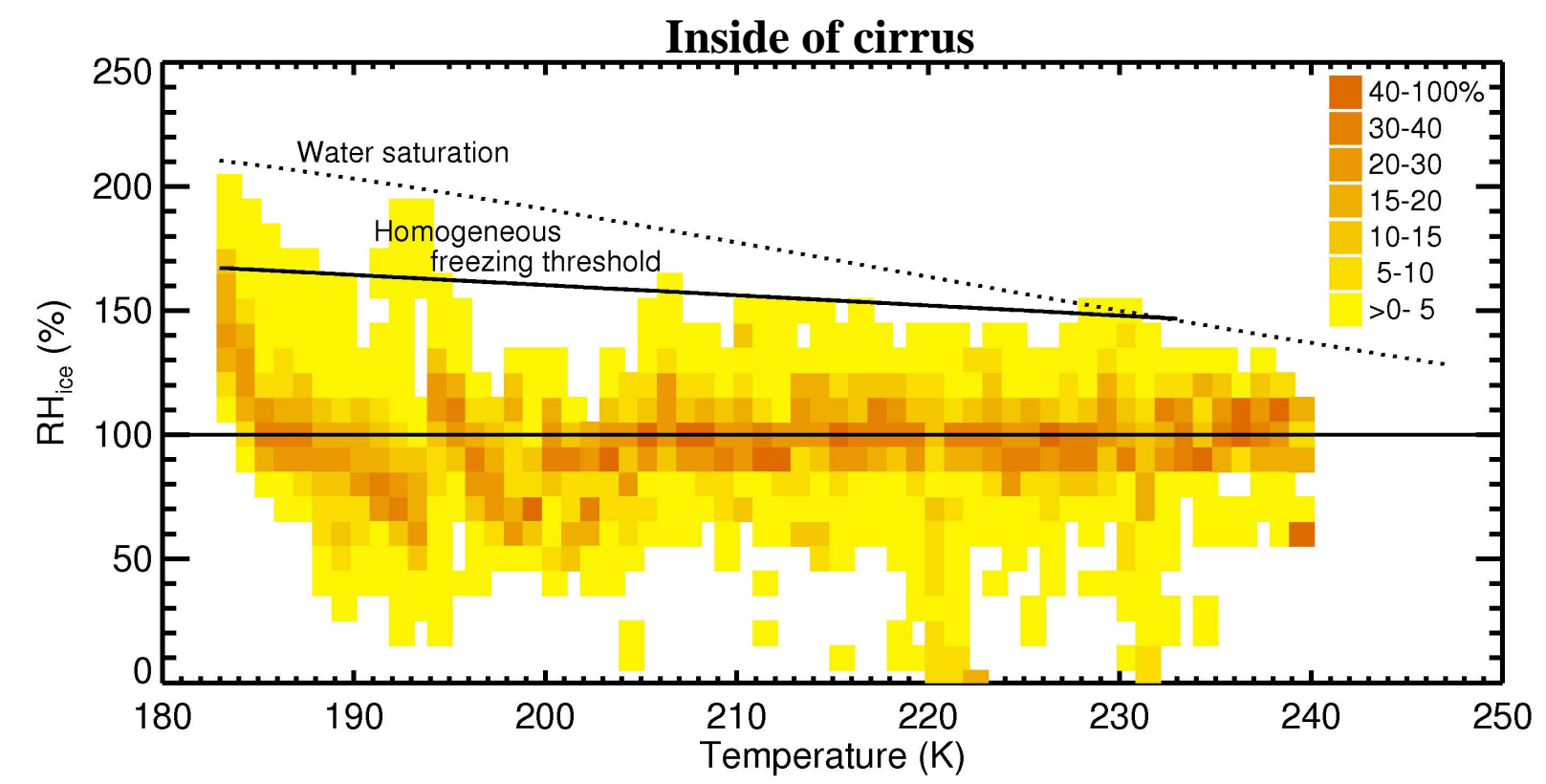

Fig. 7. Frequencies of occurrence of relative humidities over ice $\mathrm{RH}_{\text {ice }}$ vs. temperature (same data set as in Fig. 3, bottom left, solid line: homogeneous freezing threshold, dotted line: water saturation line; data are sorted in $1 \mathrm{~K}$ temperature bins).

range for thick, medium and thin cirrus (dashed green, red and yellow lines in Fig. 6, left; note that natural cirrus cannot reach dynamical equilibrium when the time scale of changes in $\mathrm{u}_{\mathrm{z}}$ are shorter than $\tau$, which is the case very often). However, supersaturation strongly increases with decreasing temperatures. This increase is caused mainly by the decrease of $\mathrm{N}_{\mathrm{i}} \mathrm{R}_{\mathrm{i}}$ with decreasing temperature, combined with the effect that the water vapour transport slows down with decreasing temperature. Together, the gas phase depletion of water by transport to the ice crystals cannot completely compensate the fast decrease of the saturation water vapour pressure.

Enhanced time is needed to transport the water vapour if fewer ice crystals are present. Thus, the relaxation times before reaching dynamical equilibrium differ greatly with the ice crystal number: for thick ice clouds (green dashed line in Fig. 6, top), dynamical equilibrium is reached very quickly in the time scale of $0.3-2 \mathrm{~s}$ with decreasing temperature, for medium clouds the relaxation time rises to $4 \mathrm{~s}-$ $20 \mathrm{~min}$ and thin ice clouds needs $1-3 \mathrm{~h}$ to relax to equilibrium. That means supersaturation can live longer the thinner the ice cloud is. This is also seen from observations by Ström and Kärcher (2003) during the INCA experiment (temperature range 215-235 K, their Fig. 4), showing that the fraction of in-cloud data points between 80 and $140 \% \mathrm{RH}_{\text {ice }}$ increases significantly with decreasing number of ice crystals.

For low temperatures with high equilibrium supersaturations and relaxation times, it follows that for the complete atmospheric range of ice crystal concentrations saturation inside of ice clouds can hardly be reached as long as the cloud is further cooled. Intensifying the cooling rate would force
$\mathrm{RH}_{\mathrm{qsi}}$ towards higher $\mathrm{RH}_{\mathrm{qsi}}$ (not shown here), while reduced cooling forces $\mathrm{RH}_{\mathrm{qsi}}$ towards saturation. However, a dynamical equilibrium $\mathrm{RH}_{\mathrm{qsi}}$ of around $100 \%$ is only reached when $\mathrm{u}_{\mathrm{z}}$ slows down to very low values in older thick, medium and thin ice clouds (Fig. 6, bottom, dashed-dotted lines). The time scales are nearly identical at higher temperatures and are a little longer at lower temperatures.

When comparing the calculated range of $\mathrm{RH}_{\mathrm{qsi}}$ with the supersaturations observed inside of cirrus (Fig. 3, bottom left panel) it must be taken into account that before reaching dynamical equilibrium the supersaturations in cirrus are higher, because they start at the freezing threshold at the formation of the cloud. Then, the comparison shows that for the range of $\mathrm{N}_{\mathrm{i}} \mathrm{R}_{\mathrm{i}}$ considered here the observed supersaturations can be explained by conventional microphysics.

\subsection{Frequencies of supersaturations and ice crystal numbers}

As for the clear sky data set, frequencies of occurrence of in-cloud $\mathrm{RH}_{\text {ice }}$ binned in $1 \mathrm{~K}$ temperature intervals are derived from the field observations shown in Fig. 3 (bottom left panel) and plotted in Fig. 7. In Fig. 8, the frequency distributions of $\mathrm{RH}_{\text {ice }}$ are binned into two temperature ranges, namely above and below $205 \mathrm{~K}$.

At temperatures above about $205 \mathrm{~K}$, most of the $\mathrm{RH}_{\text {ice }}$ observations group around $100 \%$. This finding is in agreement with the observations during the mid-latitude experiment INCA (Ovarlez et al., 2002, their Fig. 4 and Gayet et al., 2004, their Fig. 5). Higher supersaturations are less frequent and probably observed in young cirrus directly after ice 
formation, while subsaturations are aged cirrus in the evaporation stage. The narrowness of the distribution is consistent with short water vapour relaxation times in this temperature range, causing these parts of the cloud life cycle to be short compared to the time the clouds live around saturation.

At temperatures lower than about $205 \mathrm{~K}$, the grouping of the $\mathrm{RH}_{\text {ice }}$ frequencies of occurrence around saturation broadens. A small part of this broadening $(\sim 10 \%)$ can be caused by the precision of the water vapour measurement, which becomes more apparent at the low mixing ratios in this temperature range. However, this effect is significantly smaller than the braodening of the distribution of relative humidity at $T<205 \mathrm{~K}$ compared to the distribution at $T>205 \mathrm{~K}$. We attribute this difference to longer water vapour relaxation times in cold cirrus. There is no clear supersaturation cycle during the cirrus lifetime in this temperature range.

To further investigate the $\mathrm{RH}_{\text {ice }}$ frequency distribution, frequencies of occurrence of $\mathrm{N}_{\text {ice }}$ (from Fig. 5) are derived similarly to the $\mathrm{RH}_{\text {ice }}$ frequencies and are shown in Fig. 9 (top panel). The minimum/middle/maximum $\mathrm{N}_{\text {ice }}$ from Fig. 5 are overlaid as thin solid lines.

The number of ice crystals that would form homogeneously for different constant vertical velocities $\mathrm{u}_{\mathrm{z}}(1,10$, $100,1000 \mathrm{~cm} / \mathrm{s}$ ) are shown as thick solid lines. They are calculated using a simple box model together with the ice microphysics as described in Spichtinger and Gierens (2009). Here, we assume only homogeneous nucleation with nucleation rates parameterized according to Koop et al. (2000) and a background concentration of sulphuric acid aerosol of $N_{a}=300 \mathrm{~cm}^{-3}$, which is typical of upper tropospheric conditions (see e.g. Minikin et al., 2003). The calculated ice crystal number concentrations can be interpreted as an upper limit for the amount of ice crystals formed in updrafts of this magnitude under atmospheric conditions.

The most obvious feature of Fig. 9 (top panel) is that the simulated ice crystal numbers formed by homogeneous freezing increase with decreasing temperature for each $\mathrm{u}_{\mathrm{z}}$, while the most frequently observed $\mathrm{N}_{\text {ice }}$ decreases, confirming and extending the observations of Gayet et al. (2006) in the temperature range $210-260 \mathrm{~K}$ during the INCA experiment.

In the following, we individually discuss the correlations between the numbers of ice crystals, supersaturations, vertical velocities $\mathrm{u}_{\mathrm{z}}$ and relaxation times $\tau$ for the two supersaturation regimes separated at $\sim 205 \mathrm{~K}$, where each temperature regime represents around $5 \mathrm{~h}$ of observations. The possible effect of shattering of large ice crystals on our findings will also be discussed.

\subsubsection{Warm cirrus $(>205 \mathrm{~K})$}

The observed grouping of $\mathrm{RH}_{\text {ice }}$ around 100\% (Fig. 7) indicates short water vapour relaxation times, which occurs in the case of high ice crystal numbers $\mathrm{N}_{\text {ice }}$ (Sect. 3.4).
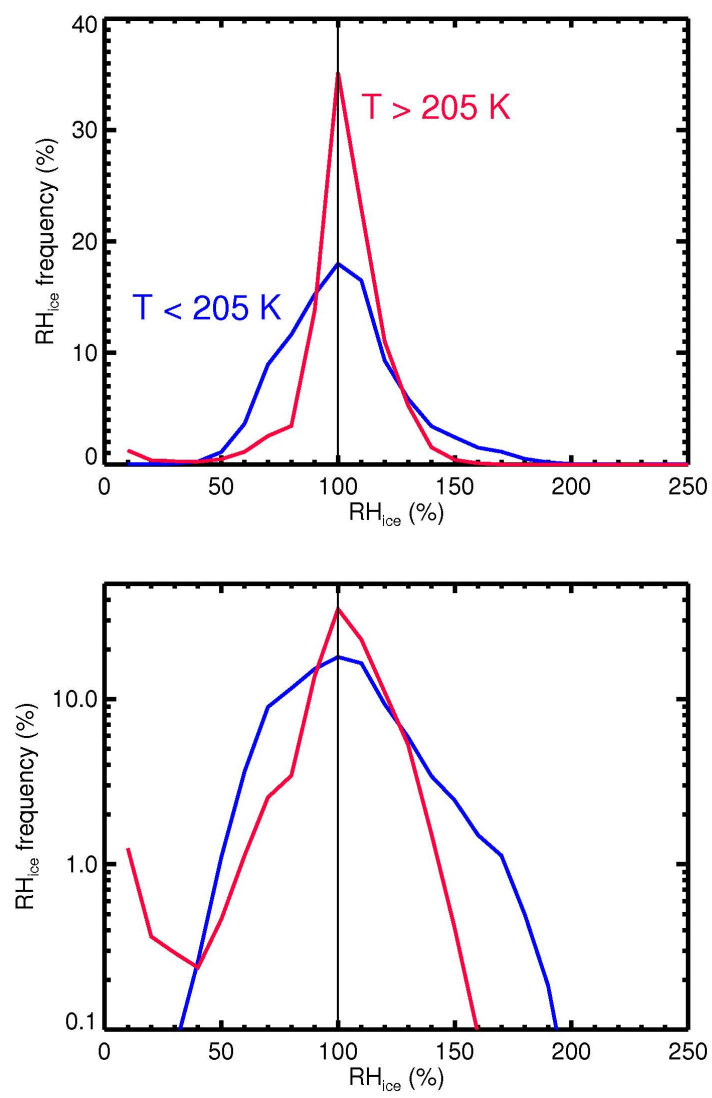

Fig. 8. Frequency distribution of $\mathrm{RH}_{\text {ice }}$ inside of cirrus for two temperature ranges (top: linear, bottom: logarithmic ordinate; red: $T>205 \mathrm{~K}, 5.6 \mathrm{~h}$ airborne in situ observations, blue: $T<205 \mathrm{~K}, 4.1 \mathrm{~h}$; same dataset as Fig. 7, bottom; data are sorted in $10 \% \mathrm{RH}_{\text {ice }}$ bins.

Indeed, high $\mathrm{N}_{\text {ice }}$ observations $\left(0.5-10 \mathrm{~cm}^{-3}\right)$ are most frequent at 225-240 K (Fig. 9, top panel). If homogeneous freezing is assumed to be the pathway of cloud formation, this corresponds to $\mathrm{u}_{\mathrm{z}}$ between 10 and $100 \mathrm{~cm} / \mathrm{s}$ or higher, as can be seen from the thick solid lines in Fig. 9 (top panel). This is in good agreement with the studies by Gayet et al. (2006) as well as Kärcher and Ström (2003), the latter reporting $1-10 \mathrm{~cm}^{-3}$ ice crystals and an updraft speed of $10-100 \mathrm{~cm} / \mathrm{s}$ in young cirrus observed in the temperature range $215-235 \mathrm{~K}$ during the INCA experiment. For such conditions, the relaxation times $\tau$ are in the range of minutes. The $\mathrm{u}_{\mathrm{z}}$ and $\tau$ ranges are estimated from the data set of $\mathrm{N}_{\text {ice }} \overline{\mathrm{R}_{\text {ice }}}$ and $\mathrm{RH}_{\text {ice }}$ using Eqs. 1 and 2 (see also Fig. 6).

At about $205-225 \mathrm{~K}$, middle $\mathrm{N}_{\text {ice }}\left(0.05-1 \mathrm{~cm}^{-3}\right)$ observations are most frequent, corresponding to $\mathrm{u}_{\mathrm{z}}$ around $5-10 \mathrm{~cm} / \mathrm{s}$. Here, $\tau$ is a little longer and ranges up to several ten minutes, but is still short enough to efficiently reduce the initial in-cloud supersaturations. 


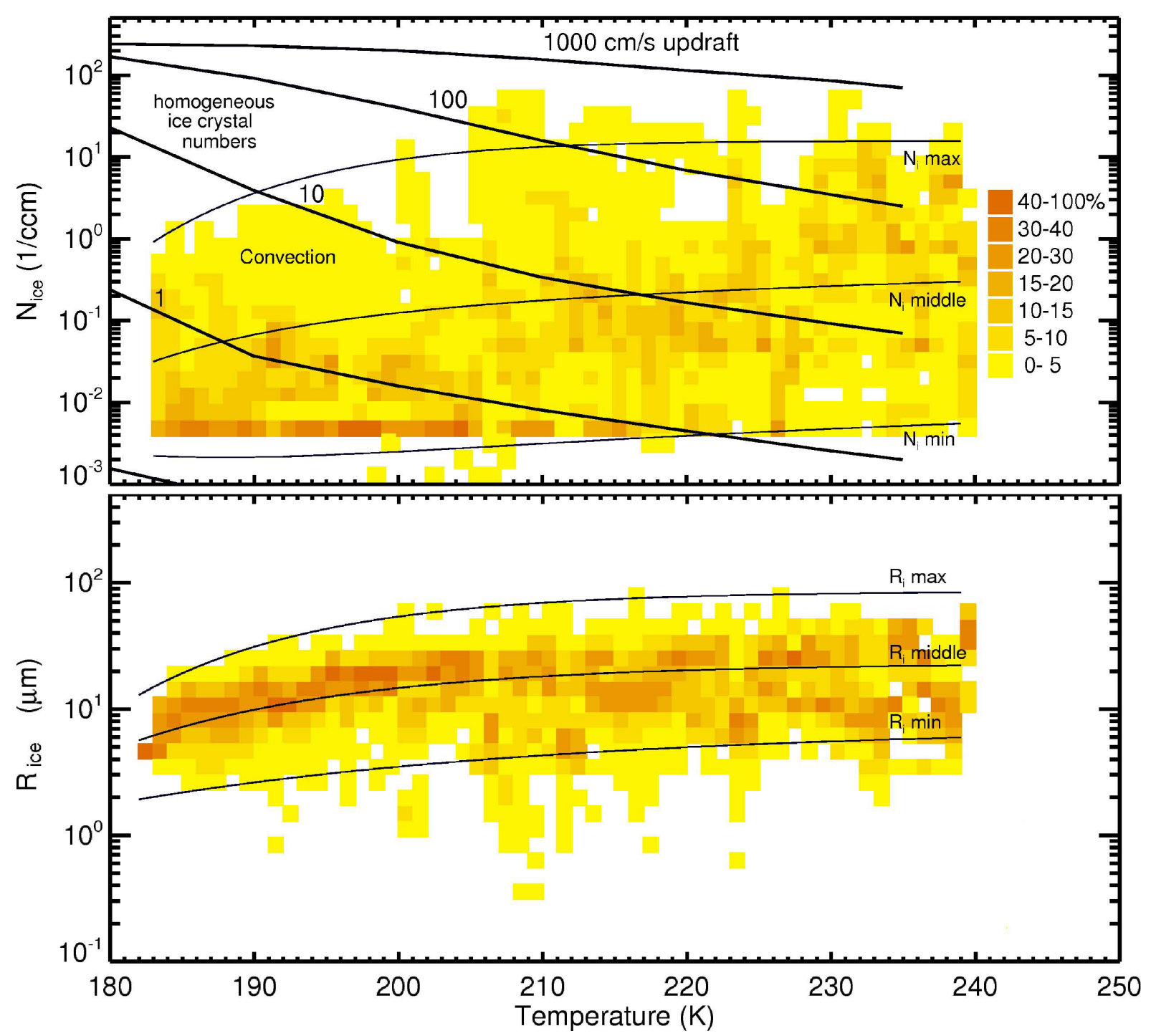

Fig. 9. Frequencies of occurrence of ice crystal numbers $\mathrm{N}_{\text {ice }}$ (top panel) and sizes $\mathrm{R}_{\text {ice }}$ (bottom panel) vs. temperature (same dataset as Fig. 5; thin solid lines: minimum, middle and maximum $\mathrm{N}_{\text {ice }}$ and $\mathrm{R}_{\text {ice }}$; thick solid lines in top panel: ice crystal numbers arising for homogeneous freezing at different updraft velocities after Koop et al. (2000) for an aerosol particle number of $300 \mathrm{~cm}^{-3}$ and mean pressure; data are sorted in $1 \mathrm{~K}$ temperature bins).

\subsubsection{Cold cirrus $(<205 \mathrm{~K})$}

As mentioned above, in the cold temperature regime no clear supersaturation pattern can be seen in Fig. 7, implying that the water vapour relaxation times are longer here. Such long relaxation times can be caused by the slower water vapour diffusion in this temperature range, or, more importantly, low ice crystal numbers and/or high vertical velocities (see Sect. 3.4).

Very low $\mathrm{N}_{\text {ice }}$ observations $\left(0.005-0.2 \mathrm{~cm}^{-3}\right)$ are most frequent at temperatures below $205 \mathrm{~K}$ (Fig. 9, top panel). Higher ice crystal numbers are found only occasionally in the upper part of convective systems (note here that the time of observation in subvisible and convective cirrus is the same, i.e. the $\mathrm{N}_{\text {ice }}$ pattern is not biased by differing sampling time; note also that FSSP samples around $90 \%$ or more of the ice crystals, see Sect. 2.2, i.e. the low ice particle numbers are not caused by missing ice crystals larger than the FSSP upper detection limit).

The very low $\mathrm{N}_{\text {ice }}$ would correspond to $\mathrm{u}_{\mathrm{z}}$ around or lower than $1 \mathrm{~cm} / \mathrm{s}$ - if they are formed by homogeneous freezing - and relaxation times $\tau$ from hours to a day. The $\mathrm{u}_{\mathrm{z}}$ range is visible in Fig. 9, top panel: the most frequent ice crystal numbers group around and below the $\mathrm{N}_{\mathrm{ice}}$ line for $\mathrm{u}_{\mathrm{z}}=1 \mathrm{~cm} / \mathrm{s}$. As a consequence, the time the water vapour needs to migrate to the few ice crystals after ice formation is so long that the high initial supersaturations, which correspond to the 
freezing thresholds, can be maintained over a longer period. Likewise, evaporation of ice crystals in a subsaturated environment occurs on a longer time scale. These considerations corroborate the fact that the observations of persistent high in-cloud supersaturations in cold cirrus can be explained by conventional ice microphysics, with unexpectedly low ice crystal numbers.

Our observations are consistent with others, for example Lawson et al. (2008) report an $\mathrm{N}_{\text {ice }}$ range of 0.002 $0.19 \mathrm{~cm}^{-3}$ at 188 to $198 \mathrm{~K}$ from $2.4 \mathrm{~h}$ of observation time in subvisible cirrus during the CR-AVE field campaign. Lawson et al. (2008) attributed the simultaneous observations of high $\mathrm{RH}_{\text {ice }}$ to the colder temperatures and aerosol chemistry in the upper TTL compared to mid-latitude cirrus.

Two model case studies simulating cirrus observations during CRYSTAL-FACE (Khvorostyanov et al., 2006), and CR-AVE (Gensch et al., 2008) also show few ice crystals and state that high supersaturations at low temperature may be explained by assuming of heterogeneous freezing. In addition, Jensen et al. (2008) report in another CR-AVE model case study that the observation of few large crystals would not have been possible in the presence of homogeneous freezing.

Several scenarios are possible to explain the low ice crystal numbers: (i) the ice clouds have formed homogeneously at very low $\mathrm{u}_{\mathrm{Z}}$ (around or lower than $1 \mathrm{~cm} / \mathrm{sec}$ ), (ii) they formed via heterogeneous ice nucleation, (iii) ice nucleation is suppressed at low temperatures (see Sect. 3.2).

Scenario (i), homogeneous freezing at very low $u_{z}$, seems unlikely, because higher $\mathrm{u}_{\mathrm{z}}$ do occur in the uppermost troposphere (Lawson et al., 2008; Jensen et al., 2008). Scenario (ii), heterogeneous freezing as sole ice nucleating mechanism, is possible (see Khvorostyanov et al., 2006 and Gensch et al., 2008), but the question arises of whether this mechanism is the most frequent in the UT. In this case, the homogeneous freezing threshold would rarely be reached after heterogeneous freezing once has occurred. Another possible candidate is (iii), the supression of ice nucleation as discussed above. If half of the particles contain organic material (Murphy et al., 2007), this could be a common mechanism. Perhaps all three ice-forming processes occur in the uppermost troposphere with probabilities increasing from (i) to (iii).

\subsubsection{Ice crystal shattering}

Shattering of larger ice crystals may have enhanced the number of particles detected in the FSSP size range, especially for the temperature range $>205 \mathrm{~K}$ (see Sect. 2.2). The good agreement of our $\mathrm{N}_{\text {ice }}$ observations with those reported from INCA in this temperature range (see Sect. 3.5.1) may be due to the same shattering problems as speculated by Jensen et al. (2009). Assuming that the most frequent $\mathrm{N}_{\text {ice }}$ concentrations are lower and lie between the middle and minimum $\mathrm{N}_{\text {ice }}$ in Fig. 9 (top panel), this implies either that the vertical ve- locities inducing homogeneous freezing are not higher than about $20 \mathrm{~cm} / \mathrm{s}$, or that heterogeneous freezing is a major process in this temperature range. Neither of these assumptions are in agreement with current knowledge on cirrus production processes. In addition, the cloud relaxation times would then extend to approx. 5 to $60 \mathrm{~min}$ (Fig. 6), causing a longer lifetime at high supersaturation. We question whether this scenario is consistent with the narrow $\mathrm{RH}_{\text {ice }}$ frequency distribution shown in Fig. 8.

At $T<205 \mathrm{~K}$ our observations are consistent with those reported by Lawson et al. (2008) (see Sect. 3.5.2), and, as discussed in Sect. 2.2, we do not expect an effect of ice crystal shattering at low temperatures. Considering nevertheless that shattered large ice crystals enhance $\mathrm{N}_{\text {ice }}$ at low temperatures in our data set and the real ice crystal concentrations are smaller, implies - as for the higher temperatures - that the relaxation times are longer and the steady-state supersaturations becomes higher and exist over a longer period. Thus, our conclusion that the frequent observation of high supersaturations at low temperatures can be explained by conventional microphysics receives even stronger support.

In conclusion, we believe that shattering may occasionally influence the observed $\mathrm{N}_{\text {ice }}$, especially at higher temperatures. However, these cases do not significantly impact the pattern of the $\mathrm{N}_{\text {ice }}$ frequencies presented here or the results and conclusions derived from these measurements.

\section{Conclusions}

We studied the upper tropospheric humidity in- and outside of cirrus clouds, motivated by the current discussion of persistent supersaturations up to or even above water saturation reported in recent years especially at low temperatures (Peter et al., 2006, 2008). A variety of hypotheses are discussed in an attempt to understand the observations, but a key question raised in these studies is the quality of the water measurements. Here, we presented an extensive in situ data set of thoroughly quality checked clear sky and in-cloud aircraft observations of relative humidity as well as ice crystal numbers in the temperature range 183-240 K (see Sect. 2).

In clear sky and inside of cirrus clouds we observed explainable supersaturations up to the homogeneous freezing threshold over the complete temperature range. At $T<200 \mathrm{~K}$, a small fraction of supersaturations slightly above the homogeneous freezing threshold but well below water saturation are found. The observations allow the following conclusions.

Clear sky supersaturations: From our robust data set cases of slight freezing suppression in cold ice clouds could be derived (see Sect. 3.2), but a severe suppression of ice formation that raises the clear sky supersaturation to values above water saturation is not seen. We support the idea that this freezing suppression is caused by the composition of the aerosol particles. We do not rule out here an impact of other hypotheses to explain high supersaturations (see Peter et al., 
2006, 2008), such as a low mass accommodation of $\mathrm{H}_{2} \mathrm{O}$ on aerosol particles or an underestimation of the vapour pressure of supercooled water, but altogether we do not observe a large effect on the ice formation in the upper troposphere.

In-cloud supersaturations: Likewise, no processes severely hindering the growth of ice crystals while holding up the supersaturation are necessary to explain our observations inside of clouds (see Sects. 3.3 and 3.4). However, as for clear sky, we do not rule out the possibility that several mechanisms summarized and discussed by (Peter et al., 2006, 2008, and references therein) might influence the depletion of water vapour by growing ice crystals: a low mass accommodation of $\mathrm{H}_{2} \mathrm{O}$ on ice, nitric acid deposition on ice forming NAT or cubic ice formation. However, from our data set we cannot deduce a large effect on ice growth.

Supersaturations and ice crystal numbers: Persistent high - but below the homogeneous freezing threshold - supersaturations at low temperatures are found in our measurements. The key parameter explaining these observations is the number of ice crystals, which is unexpectedly low in most cases (see Sect. 3.5). Several scenarios are proposed to explain these low ice crystal numbers: (i) the ice clouds have formed homogeneously at very low $\mathrm{u}_{\mathrm{z}}$ (around or lower $1 \mathrm{~cm} / \mathrm{sec}$ ), (ii) they formed via heterogeneous ice nucleation, (iii) ice nucleation is suppressed at low temperatures. We speculate that all three ice-forming processes occur in the uppermost troposphere with differing probabilities.

Considering this hypothesis together with our clear sky and in-cloud supersaturation as well as ice crystal number field observations yields a consistent picture for low temperatures: a combination of the different ice-forming processes would produce clear sky and in-cloud supersaturations up to values above the homogeneous freezing threshold as well as low ice crystal numbers, which in turn causes persistent super- and subsaturations.

In summary, we confirm the existence of supersaturations up to the homogeneous freezing threshold and sometimes slightly above in- and outside of cirrus clouds. We explain the observations by conventional knowledge of cloud microphysics. Especially, high persisent supersaturations at low temperatures are traced back to low ice crystal numbers, which however are not yet fully understood.

Acknowledgements. We would like to thank A. Korolev for fruitful discussions and for giving us the code for the dynamical equilibrium calculations. T. Peter is kindly acknowledged for continuous stimulating debates. We also gratefully acknowledge, J. Beuermann, M. Bläsner, O. Bujok, N. Eicke, S. Rohs, F. H. Silva dos Santos, A. Schönfeld, V. Tan and M. Zöger who were involved in the experimental work during the different campaigns, as well as the aircraft teams of DLR Oberpfaffenhofen, GfD Hohn, enviscope Frankfurt and MDB Moscow and the coordinators of the different field experiments. In addition, we thank J. Carter-Sigglow from the Language Services of Forschungszentrum Jülich for improving the English language of the manuscript.
Funding for the campaigns was granted by the BMBF within the "Ozonforschungsprogramm" and the "Angewandte Klima- und Atmosphärenforschung" programme, by the EU DG XII within Framework Programmes 5 and 6, and by ESA within the ENVISAT validation programme. Water vapour measurements by FLASH and data preparation was supported by the Russian Foundation for Basic Research grants No. 06-05-64165-a and 07-05-00486-a. This work was partly supported by the European Commission within the framework of the Marie Curie Fellowship "Impact of mesoscale dynamics and aerosols on the life cycle of cirrus clouds (IMDALCC)".

Edited by: T. Garrett

\section{References}

Beaver, M. R., Elrod, M. J., Garland, R. M., and Tolbert, M. A.: Ice nucleation in sulfuric acid/organic aerosols: implications for cirrus cloud formation, Atmos. Chem. Phys., 6, 3231-3242, 2006, http://www.atmos-chem-phys.net/6/3231/2006/.

Comstock, J., Ackerman, T. P., and Turner, D.: Evidence of high ice supersaturation in cirrus clouds using ARM Raman lidar measurements, Geophys. Res. Lett., 31, L11106, doi:10.1029/ 2004GL019705, 2004.

Comstock, J., Ackerman, T. P., and Turner, D.: Understanding ice supersaturation, particle growth, and number concentration in cirrus clouds, J. Geophys. Res., 113, D23211, doi:10.1029/ 2008JD010332, 2008.

Davis, S., Avallone, L., Kahn, B., Meyer, K., and Baumgardner, D.: Comparison of airborne in situ measurements and Moderate Resolution Imaging Spectroradiometer (MODIS) retrievals of cirrus cloud optical and microphysical properties during the Midlatitude Cirrus Experiment (MidCiX), J. Geophys. Res., 114, D02203, doi:10.1029/2008JD010284, 2009.

de Reus, M., Borrmann, S., Heymsfield, A. J., Weigel, R., Schiller, C., Mitev, V., Frey, W., Kunkel, D., Kürten, A., Curtius, J., Sitnikov, N. M., Ulanovsky, A., and Ravegnani, F.: Evidence for ice particles in the tropical stratosphere from in-situ measurements, Atmos. Chem. Phys. Discuss., 8, 19313-19355, 2008, http://www.atmos-chem-phys-discuss.net/8/19313/2008/.

Field, P., Heymsfield, A., and Bansemer, A.: Shattering and particle interarrival times measured by optical array probes in ice clouds, J. Atmos. Ocean. Tech., 23, 1357-1371, 2006 a.

Field, P., Wood, R., Brown, P., Kaye, P. H., Hirst, E., Greenaway, R., and Smith, J.: Ice particle interarrival times measured with a fast FSSP, J. Atmos. Ocean. Tech., 20, 249-261, 2006b.

Gao, R., Popp, P., Fahey, D., Marcy, T., Herman, R., Weinstock, E., Baumgardener, D., Garrett, T., Rosenlof, K., Thompson, T., Bui, P., Ridley, B., Wofsy, S., Toon, B., Tolbert, M., Kärcher, B., Peter, T., Hudson, P., Weinheimer, A., and Heymsfield, A.: Evidence That Nitric Acid Increases Relative Humidity in LowTemperature Cirrus Clouds, Science, 303, 516-520, 2004.

Gardiner, B. and Hallett, J.: Degradation of in-cloud forward scattering spectrometer probe measurements in the presence of ice particles, J. Atmos. Ocean. Tech., 2, 171-180, 1985.

Gayet, J.-F., Ovarlez, J., Shcherbakov, V., Ström, M., Schumann, U., Minikin, A., Auriol, F., Petzold, A., and Monier, M.: Cirrus cloud microphysical and optical properties at southern and northern midlatitudes during the INCA experiment, J. Geophys. Res., 109, D20206, doi:10.1029/2004JD004803, 2004. 
Gayet, J.-F., Shcherbakov, V., Mannstein, H., Minikin, A., Schumann, U., Ström, J., Petzold, A., Ovarlez, J., and Immler, F.: Microphysical and optical properties of midlatitude cirrus clouds observed in the southern hemisphere during INCA experiment, Q. J. Roy. Meteor. Soc., 132, 2719-2748, doi:10.1256/qj.05.162, 2006.

Gensch, I., Bunz, H., Baumgardner, D., Christensen, L., Fahey, D., Hermann, R., Lawson, P., Popp, P., Smith, J., Webster, C., Weinstock, E., Wilson, J., Peter, T., and Krämer, M.: Supersaturations, Microphysics and Nitric Acid Partitioning in a Cold Cirrus observed during CR-AVE 2006: An Observation-Modeling Intercomparison Study., Environ. Res. Lett., 3, 035003, doi: 10.1088/1748-9326/3/3/035003, 2008.

Gettelman, A. and Kinnison, D. E.: The global impact of supersaturation in a coupled chemistry-climate model, Atmos. Chem. Phys., 7, 1629-1643, 2007,

http://www.atmos-chem-phys.net/7/1629/2007/.

Gettelman, A., Fetzer, E., Eldering, A., and Irion, F.: The Global Distribution of Supersaturation in the Upper Troposphere from the Atmospheric Infrared Sounder, J. Climate, 19, 6089-6103, 2006.

Gierens, K., Schumann, U., Helten, M., Smit, H., and Marenco, A.: A distribution law for relative humidity in the upper troposphere and lower stratosphere derived from three years of MOZAIC measurements, Ann. Geophys., 17, 1218-1226, 1999,

http://www.ann-geophys.net/17/1218/1999/.

Gierens, K., Schumann, U., Helten, M., Smit, H., and Wang, P.: Ice-supersaturated regions and subvisible cirrus in the northern midlatitude upper troposphere, J. Geophys. Res., 105, 2274322753, 2000.

Glückauf, E.: Notes on upper air hygrometry - II: On the humidity in the stratosphere, Q. J. Roy. Meteor. Soc., 71, 110-112, 1945.

Haag, W., Kärcher, B., Ström, J., Minikin, A., Lohmann, U., Ovarlez, J., and Stohl, A.: Freezing thresholds and cirrus cloud formation mechanisms inferred from in situ measurements of relative humidity, Atmos. Chem. Phys., 3, 1791-1806, 2003, http://www.atmos-chem-phys.net/3/1791/2003/.

Heymsfield, A. and Milosevitch, L.: Relative humidity and temperature influences on cirrus formation and evolution: obeservations from wave clouds and FIRE II, J. Atmos. Sci., 52, 4302-4326, 1995.

Heymsfield, A., Miloshevich, L., and Twohy, C.: Uppertropospheric relative humidity observations and implications for cirrus ice nucleation, Geophys. Res. Lett., 25, 1343-1346, 1998.

Hoyle, C., Luo, B., and Peter, T.: The Origin of High Ice Crystal Number Densities in Cirrus Clouds, J. Atmos. Sci., 62, 25682579, 2005.

Immler, F., Treffeisen, R., Engelbart, D., Krüger, K., and Schrems, O.: Cirrus, contrails, and ice supersaturated regions in high pressure systems at northern mid latitudes, Atmos. Chem. Phys., 8, 1689-1699, 2008, http://www.atmos-chem-phys.net/8/1689/2008/.

Jensen, E., Toon, O., Vay, S., Ovarlez, J., May, R., Bui, T., Twohy, C., Gandrud, B., Pueschel, R., and Schumann, U.: Prevalence of ice-supersaturated regions in the upper troposphere: Implications for optically thin ice cloud formation, J. Geophys. Res., 106, 17253-17266, 2001.

Jensen, E., Pfister, L., Bui, T., Weinheimer, A., Weinstock, E., Smith, J., Pittman, J., Baumgardner, D., and Lawson, P.: For- mation of a tropopause cirrus layer observed over Florida during CRYSTAL-FACE , J. Geophys. Res., 110, D03208, doi: 10.1029/2004JD004671, 2005a.

Jensen, E. J., Smith, J. B., Pfister, L., Pittman, J. V., Weinstock, E. M., Sayres, D. S., Herman, R. L., Troy, R. F., Rosenlof, K., Thompson, T. L., Fridlind, A. M., Hudson, P. K., Cziczo, D. J., Heymsfield, A. J., Schmitt, C., and Wilson, J. C.: Ice supersaturations exceeding $100 \%$ at the cold tropical tropopause: implications for cirrus formation and dehydration, Atmos. Chem. Phys., 5, 851-862, 2005b, http://www.atmos-chem-phys.net/5/851/2005/.

Jensen, E. J., Pfister, L., Bui, T. V., Lawson, P., Baker, B., Mo, Q., Baumgardner, D., Weinstock, E. M., Smith, J. B., Moyer, E. J., Hanisco, T. F., Sayres, D. S., Clair, J. M. St., Alexander, M. J., Toon, O. B., and Smith, J. A.: Formation of large $(\simeq 100 \mu \mathrm{m})$ ice crystals near the tropical tropopause, Atmos. Chem. Phys., 8, 1621-1633, 2008, http://www.atmos-chem-phys.net/8/1621/2008/.

Jensen, E. J., Lawson, P., Baker, B., Pilson, B., Mo, Q., Heymsfield, A. J., Bansemer, A., Bui, T.P., McGill, M., Hlavka, D., Heymsfield, G., Platnick, S., Arnold, G. T., and Tanelli, S.: On the importance of small ice crystals in tropical anvil cirrus, Atmos. Chem. Phys. Discuss., 9, 5321-5370, 2009, http://www.atmos-chem-phys-discuss.net/9/5321/2009/.

Kelly, K., Proffitt, M., Chan, R., Loewenstein, M., Podolske, J., Strahan, E., Wilson, J., and Kley, D.: Water Vapor and Cloud Water Measurements Over Darwin During the STEP 1987 TropicalMission, J. Geophys. Res., 98, 8713-8723, 1993.

Khvorostyanov, V., Morrison, H., Curry, J., Baumgardner, D., and Lawson, P.: High supersaturation and modes of ice nucleation in thin tropopause cirrus: Simulation of the 13 July 2002 Cirrus Regional Study of Tropical Anvils and Cirrus Layers case, J. Geophys. Res., 111, D02201, doi:10.1029/2004JD005235, 2006.

Koop, T., Luo, B., Tsias, A., and Peter, T.: Water activity as the determinant for homogeneous ice nucleation in aqueous solutions, Nature, 406, 611-614, 2000.

Korolev, A. and Isaac, G.: Relative Humidity in Liquid, MixedPhase, and Ice Clouds, J. Atmos. Sci., 63, 2865-2880, 2006.

Korolev, A. and Mazin, I.: Supersaturation of Water Vapor in Clouds, J. Atmos. Sci., 60, 2957-2976, 2003.

Krämer, M. and Afchine, A.: Sampling characteristics of inlets operated at low U/U0 ratios: new insights from computational fluid dynamics (CFX) modeling, J. Aerosol Sci., 35, 683-694, 2004.

Kärcher, B. and Koop, T.: The role of organic aerosols in homogeneous ice formation, Atmos. Chem. Phys., 5, 703-714, 2005, http://www.atmos-chem-phys.net/5/703/2005/.

Kärcher, B. and Lohmann, U.: A parameterization of cirrus cloud formation: Homogeneous freezing of supercooled aerosols, J. Geophys. Res., 107, D24010, doi:10.1029/2002JD003220, 2002.

Kärcher, B. and Ström, J.: The roles of dynamical variability and aerosols in cirrus cloud formation, Atmos. Chem. Phys., 3, 823838, 2003, http://www.atmos-chem-phys.net/3/823/2003/.

Lawson, R. P., Pilson, B., Baker, B., Mo, Q., Jensen, E., Pfister, L., and Bui, P.: Aircraft measurements of microphysical properties of subvisible cirrus in the tropical tropopause layer, Atmos. Chem. Phys., 8, 1609-1620, 2008, http://www.atmos-chem-phys.net/8/1609/2008/.

Lee, S.-H., Wilson, J., Baumgardner, D., Herman, R., Weinstock, E., LaFleur, B., Kok, G., Anderson, B., Lawson, P., Baker, B., 
Strawa, A., Pittman, J., Reeves, J., and Bui, T.: New particle formation observed in the tropical/subtropical cirrus clouds, J. Geophys. Res., 109, D20209, doi:10.1029/2004JD005033, 2004. MacKenzie, A., Schiller, C., Peter, T., Adriani, A., Beuermann, J., Bujok, O., Cairo, F., Corti, T., DiDonfrancesco, G., Gensch, I., Kiemle, C., Krämer, M., Rohs, S., Rudakov, V., Kroger, C., Merkulov, S., Oulanovsky, A., Ravegnani, F., Salter, P., Santacesaria, V., Stefanutti, L., and Yushkov, V.: Tropopause and hygropause variability over the equatorial Indian Ocean during February and March 1999, J. Geophys. Res., 111, D18112, doi: 10.1029/2005JD006639, 2006.

Marti, J. and Mauersberger, K.: A survey and new measurements of ice vapor pressure at temperatures between $170 \mathrm{~K}$ and $250 \mathrm{~K}$, Geophys. Res. Lett., 20, 363-366, 1993.

May, R. and Webster, C.: Data Processing and Calibration for Tunable Diode Laser Harmonic Absorption Spectrometers, J. Quant. Spectrosc. Ra., 49, 335-347, 1993.

McFarquhar, G., Junshik, U., Freer, M., Baumgardner, D., Kok, G., and Mace, G.: The Importance of Small Ice Crystals to Cirrus Properties: Observations from the Tropical Warm Pool International Cloud Experiment (TWP-ICE), Geophys. Res. Lett., 34, L13803, doi:10.1029/2007GL029865, 2007.

Minikin, A., Petzold, A., Ström, J., Krejci, R., Seifert, M., van Velthoven, P., Schlager, H., and Schumann, U.: Aircraft observations of the upper tropospheric fine particle aerosol in the Northern and Southern Hemispheres at midlatitudes, Geophys. Res. Lett., 30, 1503, doi:10.1029/2002GL016458, 2003.

Möhler, O., Büttner, S., Linke, C., Schnaiter, M., Saathoff, H., Stetzer, O., Wagner, R., Krämer, M., Mangold, A., Ebert, V., and Schurath, U.: Effect of sulfuric acid coating on heterogeneous ice nucleation by soot aerosol particles, J. Geophys. Res., 110, D11210, doi:10.1029/2004JD005169, 2005a.

Möhler, O., Linke, C., Saathoff, H., Schnaiter, M., Wagner, R., Mangold, A., Krämer, M., and Schurath, U.: Ice nucleation on flame soot aerosol of different organic carbon content, Meteorol. Z., 14, 477-484, 2005b.

Möhler, O., Field, P. R., Connolly, P., Benz, S., Saathoff, H., Schnaiter, M., Wagner, R., Cotton, R., Krämer, M., Mangold, A., and Heymsfield, A. J.: Efficiency of the deposition mode ice nucleation on mineral dust particles, Atmos. Chem. Phys., 6, 30073021, 2006, http://www.atmos-chem-phys.net/6/3007/2006/.

Möhler, O., Benz, S., Saathoff, H., Schnaiter, M., Wagner, R., Schneider, J., Walter, S., Ebert, V., and Wagner, S.: The effect of organic coating on the heterogeneous ice nucleation efficiency of mineral dust aerosols, Environ. Res. Lett., 3, 025007 , doi:10.1088/1748-9326/3/2/025007, 2008.

Murphy, D., Cziczo, D., Hudson, P., and Thomson, D.: Carbonaceous material in aerosol particles in the lower stratosphere and tropopause region, J. Geophys. Res., 112, D04203, doi: 10.1029/2006JD007297, 2007.

Murray, B. J.: Inhibition of ice crystallisation in highly viscous aqueous organic acid droplets, Atmos. Chem. Phys., 8, 54235433, 2008, http://www.atmos-chem-phys.net/8/5423/2008/.

Ovarlez, J., Gayet, J.-F., Gierens, K., Ström, J., Ovarlez, H., Auriol, F., Busen, R., and Schumann, U.: Water vapour measurements inside cirrus clouds in Northern and Southern hemispheres during INCA, Geophys. Res. Lett., 29, 1813, doi:10.1029/2001GL014440, 2002.
Peter, T., Marcolli, C., Spichtinger, P., Corti, T., Baker, M., and Koop, T.: When dry air is too humid, Science, 314, 1399-1401, 2006.

Peter, T., Krämer, M., and Möhler, O.: Upper Tropospheric Humidity: A Report on an International Workshop, SPARC Newsletter, 9-15, 2008.

Popp, P., Marcy, T., Watts, L., Gao, R., Fahey, D., Weinstock, E., Smith, J., Herman, R., Troy, R., Webster, C., Christensen, L., Baumgardner, D., Voigt, C., Kärcher, B., Wilson, J., Mahoney, M., Jensen, E., and Bui, T.: Condensed-phase nitric acid in a tropical subvisible cirrus cloud, Geophys. Res. Lett., 34, L24812, doi:10.1029/2007GL031832, 2007.

Schiller, C., Krämer, M., Afchine, A., Spelten, N., and Sitnikov, N.: The ice Water Content in Arctic, Midlatitude and Tropical Cirrus, J. Geophys. Res., 113, D24208, doi:10.1029/2008JD010342, 2008.

Sitnikov, N., Yushkov, V., Afchine, A., Korshunov, L., Astakhov, V., Ulanovskii, A., Krämer, M., Mangold, A., Schiller, C., and Ravegnani, F.: The FLASH Instrument for Water Vapor Measurements on Board the High-Altitude Airplane, Instrum. Exp. Tech.+, 50, 113-121, 2007.

Spichtinger, P. and Gierens, K. M.: Modelling of cirrus clouds Part 1a: Model description and validation, Atmos. Chem. Phys., 9, 685-706, 2009, http://www.atmos-chem-phys.net/9/685/2009/.

Spichtinger, P., Gierens, K., and Read, W.: The global distribution of ice supersaturated regions as seen by the microwave limb sounder., Q. J. Roy. Meteor. Soc., 129, 3391-3410, 2003.

Spichtinger, P., Gierens, K., Smit, H. G. J., Ovarlez, J., and Gayet, J.-F.: On the distribution of relative humidity in cirrus clouds, Atmos. Chem. Phys., 4, 639-647, 2004, http://www.atmos-chem-phys.net/4/639/2004/.

Ström, J., Seifert, M., Kärcher, B., Ovarlez, J., Minikin, A., Gayet, J.-F., Krejci, R., Petzold, A., Auriol, F., Haag, W., Busen, R., Schumann, U., and Hansson, H. C.: Cirrus cloud occurrence as function of ambient relative humidity: a comparison of observations obtained during the INCA experiment, Atmos. Chem. Phys., 3, 1807-1816, 2003, http://www.atmos-chem-phys.net/3/1807/2003/.

Tabazadeh, A., Toon, O., Clegg, S. and Hamill, P.: A New Parameterization of $\mathrm{H}_{2} \mathrm{SO}_{4} / \mathrm{H}_{2} \mathrm{O}$ Aerosol Composition: Atmospheric Implications, Geophys. Res. Lett., 24(15), 1931-1934, 1997.

Wall, E.: Material zur Frage der Eiskeimbildung in der Atmosphäre, Meteorol. Z., 59, 109-120, 1942.

Weickmann, H.: Formen und Bildung atmosphärischer Eiskristalle, Beitr. Phys. Atmos., 28, 12-52, 1945.

Zobrist, B., Marcolli, C., Pedernera, D. A., and Koop, T.: Do atmospheric aerosols form glasses?, Atmos. Chem. Phys., 8, 52215244, 2008, http://www.atmos-chem-phys.net/8/5221/2008/.

Zöger, M., Afchine, A., Eicke, N., Gerhards, M.-T., Klein, E., McKenna, D., Mörschel, U., Schmidt, U., Tan, V., Tuitjer, F., Woyke, T., and Schiller, C.: Fast in situ stratospheric hygrometers: A new family of balloon-borne and airborne Lymanphotofragment fluo- rescence hygrometers, J. Geophys. Res., 104, 1807-1816, 1999. 